Fournier, A. M. V., J. D. Lancaster, A. P. Yetter, C. S. Hine, T. Beckerman, J. Figge, A. Gioe, M. Greider-Wagner, D. Jen, C. Johnson, M. R. Larreur, A. Shaw, K. Wolter, M. Wood, D. K. Wu, B. J. O'Neal, and H. M. Hagy. 2021. Nest success and nest site selection of wetland birds in a restored wetland system. Avian Conservation and Ecology 16(1):6. https://doi.org/10.5751/ACE-01782-160106

Copyright (C) 2021 by the author(s). Published here under license by the Resilience Alliance.

Research Paper

\title{
Nest success and nest site selection of wetland birds in a restored wetland system
}

\author{
Auriel M. V. Fournier ${ }^{1}$, Joseph D. Lancaster ${ }^{1,2}$, Aaron P. Yetter ${ }^{3}$, Christopher S. Hine ${ }^{3}$, Tyler Beckerman ${ }^{4,5}$, Jacob Figge $^{6}$, Antonio \\ Gioe $^{7}$, Macayla Greider-Wagner ${ }^{8}$, Devin Jen ${ }^{9}$, Cody Johnson ${ }^{10}$, Max R. Larreur ${ }^{11}$, Abigail Shaw ${ }^{12}$, Kayanna Wolter ${ }^{7}$, Michael Wood \\ ${ }^{7}$, Daniel K. Wu ${ }^{13}$, Benjamin J. O'Neal ${ }^{7}$ and Heath M. Hagy ${ }^{14,15}$ \\ ${ }^{1}$ Forbes Biological Station-Bellrose Waterfowl Research Center, Illinois Natural History Survey, Prairie Research Institute, \\ University of Illinois at Urbana-Champaign, Havana, IL, ${ }^{2}$ Current: Gulf Coast Joint Venture, Ducks Unlimited, Inc., Lafayette, \\ LA, ${ }^{3}$ Forbes Biological Station, Illinois Natural History Survey, Prairie Research Institute, University of Illinois at Urbana- \\ Champaign, Havana IL, ${ }^{4}$ University of Missouri, Champaign, IL, ${ }^{5}$ Current: U.S. Department of Agriculture, Wildlife Services, \\ Whiteman AFB, MO, ${ }^{6}$ Iowa State University, Ames, IA, ${ }^{7}$ Franklin College, Franklin, IN, ${ }^{8}$ University of Wisconsin Steven's Point, \\ College of Natural Resources, Steven's Point, WI, ${ }^{9}$ University of Illinois at Urbana-Champaign, Havana, IL, ${ }^{10}$ Eureka College, \\ Eureka, IL, ${ }^{11}$ Florida Fish and Wildlife Conservation Commission, Fort Myers, FL, ${ }^{12}$ Indiana University, Bloomington, IN, \\ ${ }^{13}$ University of Michigan, Ann Arbor, MI, ${ }^{14}$ Forbes Biological Station, Illinois Natural History Survey, Prairie Research Institute, \\ University of Illinois at Urbana-Champaign, Havana, IL, ${ }^{15}$ Current: U.S. Fish and Wildlife Service, Stanton, TN
}

ABSTRACT. Although most emergent wetlands across central North America have been destroyed or degraded, wetland restoration in recent decades has provided new habitat resources for wetland birds in agriculturally dominated landscapes. The goals of wetland restorations often include providing habitat for migratory and breeding waterfowl and other wetland birds. One such restored wetland complex in the Illinois River Valley, the Emiquon Preserve, is isolated from most flooding events of the Illinois River allowing the growth of persistent emergent vegetation that was quickly colonized by breeding wetland birds. We examined nest occurrence and variables influencing site selection, nest success, and changes in nest density across stages of the wetland succession cycle. We located 327 nests from nine species of wetland birds (American Bittern, Botaurus lentiginosus; American Coot, Fulica americana; Black-crowned Night-Heron, Nycticorax nycticorax; Black-necked Stilt, Himantopus mexicanus; Common Gallinule, Gallinula galeata; Green Heron, Butorides virescens; Least Bittern, Ixobrychus exilis; Pied-billed Grebe, Podilymbus podiceps; Sora, Porzana carolina) during $2013-2019$. Common Gallinules were more likely to nest in persistent emergent vegetation than other cover types. American Coots and Least Bitterns selected nest sites based on water depth. Black-necked Stilt and Black-crowned Night-Heron nests were less successful in deeper water. Black-necked Stilt, Black-crowned Night-Heron, and Common Gallinule nests were less successful with later initiation dates. Nest density did not vary between persistent emergent and hemi-marsh cover types. Across 2013-2019 we estimated an average of 372 nests/year for six marsh-nesting bird species at Emiquon, including two state-endangered (Common Gallinule and Black-crowned Night-Heron) and one state-threatened (Least Bittern). Wetlands restored from agricultural fields can quickly provide critical breeding habitat for marsh-nesting birds of conservation concern, although continued management is needed to provide resources to maintain persistent emergent vegetation communities as individual marshes transition through the marsh cycle.

\section{Succès de nidification et sélection des sites de nidification d'oiseaux de milieux humides dans un système de milieux humides restaurés}

RÉSUMÉ. Bien que la plupart des milieux humides du centre de l'Amérique du Nord aient été détruits ou aient subi une dégradation, leur restauration au cours des dernières décennies a fourni de nouveaux habitats pour les oiseaux dans des paysages dominés par l'agriculture. Les objectifs de restauration des milieux humides consistent souvent à fournir un habitat aux espèces de sauvagine migratrices et nicheuses et à d'autres oiseaux de ces milieux. Un de ces complexes de milieux humides restaurés dans la vallée du fleuve Illinois, l'Emiquon Preserve, est à l'abri des inondations du fleuve la plupart du temps, permettant la croissance de végétation émergente persistante, qui a été rapidement colonisée par les oiseaux nicheurs de milieux humides. Nous avons examiné la présence de nids et les variables influençant la sélection du site, le succès de nidification et les variations associées à la densité de nids au cours des étapes du cycle de succession des milieux humides. Nous avons localisé 327 nids de neuf espèces de milieux humides (Butor d'Amérique, Botaurus lentiginosus; Foulque d'Amérique, Fulica americana; Bihoreau gris, Nycticorax nycticorax; Échasse d'Amérique, Himantopus mexicanus; Gallinule d'Amérique, Gallinula galeata; Héron vert, Butorides virescens; Petit Blongios, Ixobrychus exilis; Grèbe à bec bigarré, Podilymbus podiceps; Marouette de Caroline, Porzana carolina) pendant la période de 2013 à 2019. Les gallinules étaient plus susceptibles de nicher dans la végétation émergente persistante que dans les autres types de couvert végétal. La foulque et le blongios ont choisi leur site de nidification en fonction de la profondeur de l'eau. Le succès de nidification de l'échasse et du bihoreau a été plus faible dans les milieux humides plus profonds. Le succès de nidification de l'échasse, du bihoreau et de la gallinule a été plus faible lorsque la date 
d'initiation était plus tardive. La densité des nids n'a pas varié pour les types de couvert végétal émergent persistant et semi-marécageux. De 2013 à 2019, nous avons compté 372 nids par an en moyenne pour six espèces nichant dans des marais à Emiquon, dont deux espèces en voie de disparition (la Gallinule d'Amérique et le Bihoreau gris) et une espèce menacée (le Petit Blongios) à l'échelle de l'État. Les milieux humides restaurés dans les champs agricoles peuvent rapidement fournir un habitat de reproduction essentiel aux oiseaux de marais dont la conservation est préoccupante; toutefois, une gestion continue est nécessaire pour maintenir des communautés de végétation émergente persistante au fur et à mesure que chaque marais évolue selon le cycle propre aux marais.

Key Words: marsh birds; marsh succession cycle; nest-site selection; nest success; shorebirds; wetland restoration

\section{INTRODUCTION}

After widespread draining of wetlands in major river floodplains during the 1800 s and early 1900 s, society now recognizes the ecological and anthropogenic value of floodplain wetlands and has begun to restore them at varying scales (Lemke et al. 2017a). Floodplain wetlands along major rivers of the Midwest, USA occur within a gradient of hydrological isolation from the main stem river, which establishes their form, functions, and value to wildlife and fish (Sparks et al. 1998, Lemke et al. 2018). Many floodplain wetlands that are managed for wildlife conservation and sport recreation purposes are protected to varying degrees from the river by levees of differing heights resulting in differential flood susceptibility and recurrence. Although some wetlands are passively managed for flood control and to allow access to floodplain-exploiting fish species, others are actively managed independent of the hydrology of the river to mimic the historical preanthropogenic flooding regime, i.e., drying out in summer with shallow flooding in the autumn (Hagy et al. 2017a, Lemke et al. 2017a).

Despite their occurrence in a highly altered landscape, managed floodplain wetlands are vitally important to a wide range of migratory birds, including waterfowl, rails, shorebirds, and other guilds (Hagy et al. 2017a, b, Hine et al. 2017). Many wetlanddependent birds use restored wetlands at different times of the year (Fournier et al. 2017, 2018, Hagy et al. 2017b). For example, waterfowl and shorebirds primarily use wetlands in the Midwest during autumn and spring migrations. Secretive marsh birds and other marsh-nesting species may use restored wetlands for breeding if growing season floods do not destroy habitat resources (Lemke et al. 2017b, Bradshaw et al. 2020, Monfils et al. 2020).

Emergent wetlands, i.e., wetlands with persistent and nonpersistent emergent vegetation, in midlatitude areas can provide habitat resources to a wide variety of species nearly year round (Hagy et al. 2017b, McClain et al. 2019). Emergent wetlands naturally progress through successional stages, and they are periodically reset by periods of drought, high water, or other perturbation (van der Valk and Davis 1978). In the marsh succession cycle, the initial stage of the dry marsh is characterized by many facultative plant species (plant species tolerant of the drier conditions of this stage; Bowyer et al. 2005, McClain et al. 2019). Facultative plants give way over time, with regular rainfall or flooding events, to more aquatic-tolerant species (e.g., Typha spp., submersed aquatic vegetation; Hine et al. 2017) as the marsh regenerates. After sustained high-water levels, disease, herbivory, and stress from prolonged flooding can cause marsh vegetation to degenerate. If degeneration continues, the wetland eventually reaches a lake marsh stage, where unvegetated, open water is the dominant cover type. Within a managed wetland, managers can choose to return the wetland to the dry or regenerating marsh stages, with different kinds of management disturbance, e.g., drawdown, flooding, fire, disking, tilling, mowing, or combination of techniques (Weller and Fredrickson 1973, van der Valk and Davis 1978). Managers use disturbance techniques to mimic natural disturbance that would have set back succession in different areas across the larger floodplain at different moments, creating various states concurrently, which collectively provide habitat for a diverse suite of species with preferences across the successional spectrum (Lemke et al. 2017a).

Although limited research has been conducted on the avian response to marsh succession and management, there is evidence that the stage of marsh succession can impact a wide variety of wetland-dependent birds, especially during the breeding season (Fredrickson and Taylor 1982, Hill 2015, Blake-Bradshaw 2018, Wilson et al. 2018, Fournier et al. 2019, McClain et al. 2019, Bradshaw et al. 2020). For example, drawdowns can impact marsh-breeding birds, e.g., rallids, bitterns, or grebes, as dry conditions may expose nests to a broader range of predators (Lyons et al. 2008, Hill 2015, Fournier et al. 2019). Selection of nest sites by overwater nesting species may depend on balancing factors that affect predation risks, such as distance to shore, vegetation cover and density, water depth, and others (Jobin and Picman 1997, Austin and Buhl 2011). For example, building nests in deeper water may reduce predation risk from mammalian predators but increase the risk of wave action physically degrading emergent vegetation, which may result in the nest falling into the water if the vegetation is weakened. These competing mechanisms are both likely to affect nest success of overwater nesting species, e.g., Common Gallinule Gallinula galeata, American Coot Fulica americana (Weller and Fredrickson 1973, Picman et al. 1993). Understanding the habitat resource requirements, factors that affect nest-site selection and success, and responses to the marsh cycle of marsh-breeding species is a critical step toward understanding what wetland conditions support a diverse suite of species across the distinct annual cycles.

We strategically searched for and monitored waterbird nests during late spring and summer of 2013 to 2019, allowing investigation of several aspects of waterbird ecology while restoration progressed through the marsh succession cycle. Our objectives were to evaluate nest occurrence, density, abundance, and success of marsh-nesting birds in relation to marsh succession and habitat conditions at the Emiquon Preserve in central Illinois. Our study provides empirical information on nest success and density relative to the marsh succession cycle that can be useful in determining the appropriate stage to interrupt the marsh degeneration succession and reset the cycle for a suite of migratory wetland-dependent birds. Our study also provided the necessary information on nest-site characteristics of marsh-nesting bird species in the Midwest, where data are minimal (Bannor and Kiviat 2020, Brisbin and Mowbray 2020, Hothem et al. 2020, 
Melvin and Gibbs 2020, Poole et al. 2020). Results from our study will allow managers to envision what types of wetland vegetation and water conditions work for each species in relation to the marsh succession cycle (McClain et al. 2019).

\section{METHODS}

\section{Study area}

The Nature Conservancy's (TNC) Emiquon Preserve (hereafter, Emiquon; Fig. 1) is the most substantial floodplain restoration effort to date in the Illinois River Valley (IRV) and a Ramsar Wetland of International Importance. Once a dynamic floodplain of the Illinois River containing several floodplain lakes, the area was developed into a drainage and levee district, incessantly pumped, and farmed for $\sim 80$ years (Bellrose et al. 1983, Lemke et al. 2017a). Since restoration in 2007, Emiquon has progressed through distinct successional stages, providing a clear example of the classic marsh cycle (Hine et al. 2017).

Fig. 1. Location of Emiquon Preserve along the Illinois River in Fulton County, Illinois, USA.

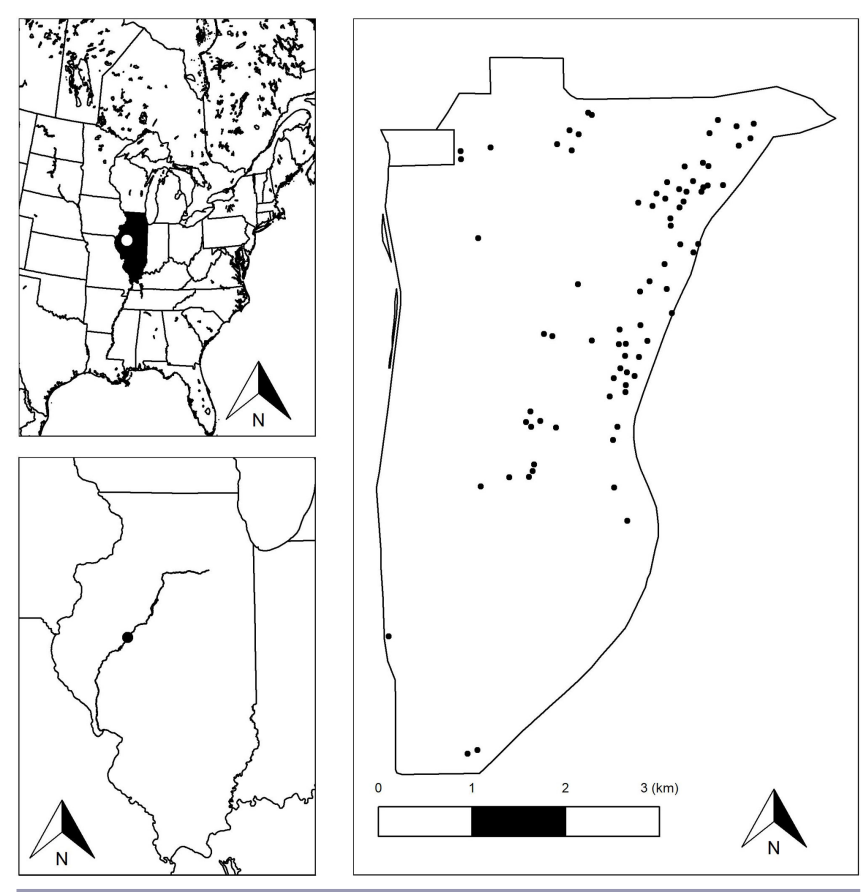

With restoration in mind, TNC suspended operation of the pumps in 2007, allowing rainwater to collect in the lakes behind the protection of the Illinois River levee. As the area continued to capture extensive rainfall in 2008 , more than 1000 ha became inundated outside the deeper lake basins. The extensive shallow inundation combined with dynamic water levels from pumping and drought in 2010 and 2012 invigorated the regenerating marsh phase resulting in abundant Typha spp., aquatic bed containing submerged and floating leaved aquatic vegetation, and deeper open water areas (Hine et al. 2017). Heavy rainfall and minor over levee flooding from the Illinois River in 2013, coupled with outflow disconnection while the water control structure and pumps were replaced in 2015-2016, caused consistently high water levels (Lemke et al. 2017b). Muskrat (Ondatra zibethicus) herbivory and prolonged inundation triggered marsh degeneration during 2014-2017, with Typha spp. beginning to die back, turning continuous patches into interspersed dead Typha spp. dotted with muskrat mounds. With much of the persistent emergent vegetation dead or dying and aquatic bed converting to open water, Emiquon had nearly completed the entire marsh cycle by 2017. The low flow of the Illinois River in autumn 2017 allowed TNC to gravity drain, lowering the surface water elevation approximately $1 \mathrm{~m}$ between August and October. Water levels rose over the 2017-2018 winter due to precipitation, which TNC then pumped out starting in May 2018, resulting in a strong response by the nonpersistent emergent wetland vegetation. Water levels were high again in spring 2019 due to overwinter precipitation, overtopping much of the facultative vegetation species, and beginning the regeneration phase of the marsh cycle. Since 2007, Emiquon has progressed through each stage of the marsh cycle, providing a diversity of vegetation communities and cover types across that time. This progression offered a unique opportunity for us to study the nest-site selection and nest success of marsh birds at different stages of wetland restoration and regeneration, a subject which has received little attention.

Emiquon has provided nesting habitat for species of conservation concern, including the American Bittern (Botaurus lentiginosus), Least Bittern (Ixobrychus exilis), Black-crowned Night-Heron (Nycticorax nycticorax), and Common Gallinule, all of which are threatened or endangered in the state of Illinois. We did not target specific bird species but instead monitored the nests of marshnesting bird species we found within our search plots, excepting passerines (e.g., Red-winged Blackbird Agelaius phoeniceus).

\section{Search plot selection and surveying}

We randomly allocated 20 circular search plots/week (50-m diameter) within Emiquon stratified on the vegetation maps completed the previous autumn by the Illinois Natural History Survey's Forbes Biological Station (Hine et al. 2017). Briefly, creating the annual cover map entailed sampling each autumn on east to west transects, $500 \mathrm{~m}$ apart, across the entire site, delineating where the vegetation communities changed along the transects, and using that data to interpolate, assisted by annual aerial photography between the transects to have a complete annual cover map of the site. Search plots (10/week/cover type) were randomly distributed within two cover types, persistent emergent (Typha spp.) and hemi-marsh emergent (open water or aquatic bed interspersed with persistent emergent vegetation in a ratio ranging from $30 \%$ to $70 \%$ by visual estimate; Hine et al. 2017). In 2018-2019, because of declining coverage of persistent emergent and hemi-marsh habitats on Emiquon, cover types were combined, and only 10 search plots/week were searched. Search plots were systematically searched for waterbird nests by multiple observers using a concentric circular search pattern where observers began $25 \mathrm{~m}$ from the search-plot center and circled inward until the entire search plot had been covered. Because observers did not have a time limit and scoured each area systematically, we assumed that detection probability was approximately 1 . Nest surveys began in late May and proceeded through late July to coincide with the presumed peak of nesting at that latitude and availability of personnel (Conway 2011). We acknowledge that some species may have nested before surveys began (e.g., Sora, Porzana carolina; Melvin and Gibbs 2020). 
Nests found outside of search plots, i.e., incidental, were also recorded, but they were not included in the density or abundance calculations. When a nest was located, we recorded latitude and longitude, species, number of eggs, incubation stage, a description of the nest bowl material and the vegetation community immediately around the nest, the height of the nest off the water, the water depth below the nest, and the turbidity of the water (Secchi disk).

\section{Nest monitoring}

All nests (from search plots and incidental discovery) were visited once a week until the nest's fate was determined. Nest visits did not exceed $15 \mathrm{~min}$ to minimize disturbance. Each week, their status was recorded (active, successful, terminated), and at least two eggs were floated to predict hatching date (Westerkov 1950). Information recorded on a given nest visit included number of eggs, the number of hatched eggs, and number of nestlings fledged. Nests were coded as a success when at least one egg hatched, or the nest was intact and unoccupied following (1-5 days) the predicted hatching date. We acknowledge that predation by animals that removed the eggs in their entirety without destroying the nest (e.g., snakes) in the few days between the predicted hatching date and our visitation date could have biased nest success high. To determine the nest initiation date, eggs were floated, and the mean float stage (1-6) was used as the estimate of age, with a day added for each egg in the clutch. All work was authorized by TNC and the Illinois Department of Natural Resources, and methods were approved by the University of Illinois at Urbana-Champaign's Institutional Animal Care and Use Committee (Protocols; 13068, 14090, 17028, 19194).

\section{Nest-site selection analysis}

Nest-site selection was modeled in a used versus available framework within single-species model sets for American Coot, Common Gallinule, and Least Bittern, which were the three species with enough observations for analysis $(n>20)$. The response variable of the binomial mixed model with a logit link was 0 or 1 , with 0 representing available habitat and 1 representing a nest. The year was considered as a random variable in all models. The plots used in this analysis are the $10 \mathrm{~m}$ radius nest and available habitat plots, where the nest plots were 1 , and the available plots were 0 . For each model set, we considered a null model, as well as several single variable models (water depth, emergent vegetation height, percent coverage open water, percent coverage persistent emergent vegetation, and categorical vegetation coverage). For the water depth model, we included a quadratic relationship because many wetland bird species have a preferred water depth range and may avoid shallower and deeper water depths (Sayre and Rundle 1984, Austin and Buhl 2011, Harms and Dinsmore 2013, Fournier et al. 2017, 2018). For other single variable models, we did not consider a quadratic relationship, because those relationships in the literature are often linear (Darrah and Krementz 2010). We chose emergent vegetation height because the height would contribute both to hiding the nests from predators, as well as potential height off the water, which could influence flooding of the nest (Hill 2015). We included two variables related to percent coverage of the nest or available habitat plot (10 $\mathrm{m}$ radius estimated visually; i.e., open water, persistent emergent vegetation) because they occur widely across the nest or available habitat plots, and are associated positively with some species (open water with American Coot; Brisbin and Mowbray 2020) and negatively with others (open water with rails; Darrah and Krementz 2011). We also included a four-category measure of vegetation coverage within the nest or available habitat plot, i.e., open water $(<30 \%$ aerial cover of emergent vegetation), persistent emergent vegetation $(>70 \%$ aerial cover of emergent vegetation), hemi-marsh vegetation (30$70 \%$ aerial cover of emergent vegetation), and upland (no surface water).

We also included several models that were combinations of the single variable models. We did not include all combinations, but instead selected models a priori based on our hypotheses about factors likely driving nest-site selection. Water depth is often considered to be a predation deterrent, so we included a model with water depth and vegetation coverage because it would represent the coarsest level of selection represented in our data. We considered a model with vegetation coverage, emergent vegetation height, and open water because this represented measures of both overall habitat and vertical and horizontal habitat structure, which is often found to be essential for marsh birds (Darrah and Krementz 2009, 2010, 2011). We also included a model with emergent vegetation height and open water as a subset of the previous model. We considered a model with habitat resource type and open water as a way of including the concept of interspersion into our data (Darrah and Krementz 2009). We considered a model with nest or available habitat plot vegetation coverage and emergent vegetation height because this represented coarser selection and the importance of vertical structure. A model with persistent emergent percent cover and quadratic water depth was included because this represents the availability of protection and water to deter predators. A model with quadratic water depth and emergent vegetation height was considered because it represents vertical structure for nest building and water for predator avoidance. Finally, we included a global model with all considered covariates, including quadratic water depth. All variables were scaled, or $\mathrm{z}$-transformed (mean $=0, \mathrm{SD}=1$ ) so that they were on comparable ranges of values.

Our models were run using the glmer function from the 'Ime4' package in R (Bates et al. 2015; R Core Team 2019, R 3.6.0, lme4 1.1-21). Models were compared with AIC with top models within two AIC of the top model being considered competitive. Marginal $\mathrm{R}^{2}$ for the top models are reported, following the methods of Nakagawa and Schielzeth (2013) and Johnson (2014).

\section{Nest success analysis}

We considered four single species model sets (American Coot, Black-necked Stilt [Himantopus mexicanus], Common Gallinule, and Least Bittern) that had enough data to stand on their own, and an all species model set (American Coot, Common Gallinule, Least Bittern, Black-crowned Night-Heron, Mallard [Anas platyrhynchos], Black-necked Stilt). We analyzed nest success using logistic-exposure models, as detailed in Shaffer (2004). Nests that were not monitored to completion or where they had insufficient evidence to assign a fate with confidence (unknown fate) were omitted from analyses $(n=24)$. We considered the same set of model predictors as those presented in nest-site selection, with the change that year was no longer considered a random effect because we are not using a mixed-effect model here. Our models used the $\operatorname{g} \operatorname{lm}()$ function, with a logistic-exposure link 
Table 1. Nests of marsh birds by species, method of detection, and year during May-August 2013-2019 at Emiquon Preserve, Fulton County, Illinois, USA.

\begin{tabular}{|c|c|c|c|c|c|c|c|c|c|}
\hline Species & Method & 2013 & 2014 & 2015 & 2016 & 2017 & 2018 & 2019 & Total \\
\hline American Bittern & Incidental & 1 & 0 & 0 & 0 & 0 & 0 & 0 & 1 \\
\hline \multicolumn{10}{|l|}{ Botaurus lentiginosus } \\
\hline American Coot & Incidental & 9 & 5 & 0 & 7 & 11 & 0 & 2 & 34 \\
\hline Fulica americana & Random & 8 & 4 & 0 & 6 & 4 & 0 & 5 & 27 \\
\hline Black-crowned Night-Heron & Incidental & 0 & 0 & 21 & 0 & 15 & 0 & 0 & 36 \\
\hline Nycticorax nycticorax & Random & 0 & 0 & 0 & 0 & 0 & 1 & 8 & 9 \\
\hline Black-necked Stilt & Incidental & 0 & 0 & 5 & 37 & 2 & 1 & 1 & 46 \\
\hline Himantopus mexicanus & Random & 0 & 0 & 0 & 2 & 0 & 0 & 0 & 2 \\
\hline Common Gallinule & Incidental & 1 & 3 & 4 & 7 & 18 & 1 & 0 & 34 \\
\hline Gallinula galeata & Random & 0 & 1 & 3 & 7 & 10 & 3 & 0 & 24 \\
\hline Green Heron & Incidental & 0 & 1 & 0 & 0 & 0 & 0 & 0 & 1 \\
\hline \multicolumn{10}{|l|}{ Butorides virescens } \\
\hline Least Bittern & Incidental & 2 & 2 & 1 & 5 & 9 & 2 & 0 & 21 \\
\hline Ixobrychus exilis & Random & 1 & 7 & 6 & 8 & 4 & 2 & 5 & 33 \\
\hline Mallard & Incidental & 0 & 0 & 10 & 5 & 11 & 0 & 0 & 26 \\
\hline Anas platyrhynchos & Random & 0 & 0 & 0 & 1 & 2 & 0 & 0 & 3 \\
\hline Pied-billed Grebe & Incidental & 0 & 2 & 0 & 6 & 1 & 0 & 0 & 9 \\
\hline \multicolumn{10}{|l|}{ Podilymbus podiceps } \\
\hline Sora & Incidental & 5 & 2 & 0 & 0 & 0 & 0 & 0 & 7 \\
\hline Porzana carolina & Random & 3 & 3 & 0 & 0 & 0 & 0 & 0 & 6 \\
\hline \multirow[t]{2}{*}{ Total } & Incidental & 18 & 15 & 41 & 67 & 67 & 4 & 3 & 215 \\
\hline & Random & 12 & 15 & 9 & 24 & 20 & 6 & 18 & 104 \\
\hline Grand Total & All & 30 & 30 & 50 & 91 & 87 & 10 & 21 & 319 \\
\hline
\end{tabular}

function in R (Bates et al. 2015, R Core Team 2019, R 3.6.0), using the log exposure code from Tyre (2017, unpublished manuscript, http://atyre2.github.io/2017/02/02/custom_link.html), also included as supplementary material.

\section{Nest density and abundance}

We estimated nest density by species and year by correcting the total nests located annually by the total area searched. We then used those estimates of density to calculate total nest abundance at Emiquon annually for each cover type by multiplying nest density by the total available area (ha) of persistent emergent and hemi-marsh vegetation communities. Area estimates were available from the Illinois Natural History Survey (Osborn et al. 2020) following methods described in Hine et al. (2017), described briefly above. We compared nest density between persistent emergent and hemi-marsh vegetation communities, with a linear model with a normal distribution with nests per search plot as the response, with only nests found in search plots included. We assessed model fit with Multiple R-squared.

\section{RESULTS}

\section{Field summary}

During 2013-2019, we searched 580 search plots for nests, which were split between persistent emergent vegetation $(40 \%)$ and hemi-marsh vegetation $(60 \% ; 2013=111,2014=90,2015=87$, $2016=74,2017=62,2018=77,2019=79)$. We located 112 nests in the search plots and 215 nests incidentally from 9 species
(American Bittern; American Coot; Black-crowned NightHeron; Black-necked Stilt; Common Gallinule; Green Heron, Butorides virescens; Least Bittern; Pied-billed Grebe, Podilymbus podiceps; Sora). American Coot, Black-necked Stilt, Common Gallinule, and Least Bittern were the most common (Table 1). Few species were found in all years, with the number and community composition shifting over time (Fig. 2). Persistent emergent vegetation declined from 297.8 ha in 2014 to 73.4 ha in 2016, but then it increased to 230 ha in 2018 following two years of summer drawdowns (Fig. 2). Hemi-marsh vegetation increased from 135.4 ha in 2014 to 290.1 ha in 2015 , concurrent with dieback of persistent emergent vegetation, but it declined to 5.4 ha in 2018 (Fig. 2).

Mean nest initiation dates were earliest for Black-crowned NightHeron (1 June), American Bittern (3 June), and Black-necked Stilt (4 June) followed by Common Gallinule (11 June), Least Bittern (14 June), Sora (16 June), American Coot (25 June), and Piedbilled Grebe (4 July). Average clutch size was highest for Mallard (6.3 eggs), Sora (5.8 eggs), and Common Gallinule (5.8 eggs) followed by American Coot (4.3 eggs), Black-necked Stilt (3.4 eggs), Pied-billed Grebe (3.4 eggs), Least Bittern (3.1 eggs), and Black-crowned Night-Heron (3.0 eggs). Although we found and monitored nests of Mallard and Sora, they typically begin nesting before our monitoring efforts, and we suspect that we recorded second nest attempts. Mean resource use varied among species (Appendix 1). 
Fig. 2. The relative proportion of nests from Common Gallinule (Gallinula galeata), Least Bittern (Ixobrychus exilis), and American Coot (Fulica americana), the three most abundant species, relative to total emergent cover type (hemimarsh and persistent emergent vegetation) during May-August 2013-2019 at Emiquon Preserve, Fulton County, Illinois, USA.
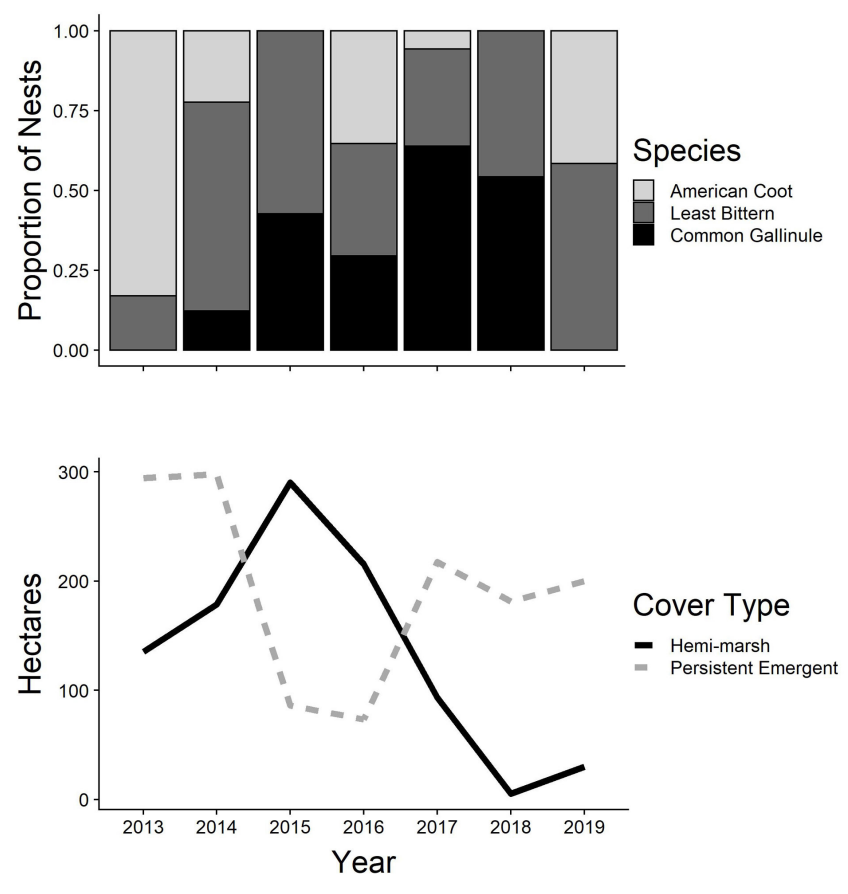

\section{Nest success}

Naive estimates of nest success varied (0.33-1.00) across species (Table 2). For the all species model set and the American Coot model set, the null model was within two $\triangle \mathrm{AIC}$ of the top model (Appendix 2). For Black-crowned Night-Heron, models containing water depth and nest initiation date were within the top models. Black-crowned Night-Heron nests were less likely to be successful in deeper water and at later initiation dates (Table 3). Black-necked Stilt nests were also less likely to be successful in deeper water and at later initiation dates (Table 3). For Common Gallinule, the top model only included initiation date (less successful nests at later dates; Table 4). For Least Bittern, the top model contained only year, with higher estimated success in 2014 and 2019 versus other years; however, standard errors were large (Table 4). The nest success data are archived as supplemental material with this paper, and we hope those data will help inform future studies/experimental designs.

\section{Nest-site selection}

Habitat resource characteristics differed among most species (Appendix 3). American Coot and Pied-billed Grebe nested in the deepest water, followed by Sora, Common Gallinule, Least Bittern, Black-crowned Night-Heron, Mallard, and Blacknecked Stilt. The proportion of persistent emergent vegetation within a 10-m buffer around nests was highest for Black-crowned Night-Heron, followed by Least Bittern, Common Gallinule,
Sora, American Coot, and Mallard. Pied-billed Grebe and Blacknecked Stilt tended to nest in open areas with $<15 \%$ cover of persistent emergent vegetation. American Coot and Common Gallinule nested in hemi-marsh vegetation while Least Bittern and Black-crowned Night-Heron commonly nested in areas with $>70 \%$ dense emergent cover. Nest height was highest for Least Bittern, followed by Common Gallinule, Sora, Black-crowned Night-Heron, and American Coot. Mallard, Pied-billed Grebe, and Black-necked Stilt nested directly on the ground or floating mats of vegetation within $3 \mathrm{~cm}$ of the water level. Approximately $88 \%$ of American Coot, $85 \%$ of Sora, $66 \%$ of Least Bittern, $62 \%$ of Black-crowned Night-heron, and $61 \%$ of Common Gallinule nests occurred where maximum vegetation height above the water ranged from 1.0-2.5 m (Fig. 3). In contrast, 96\% of Black-necked Stilt nests and $86 \%$ of Pied-billed Grebe nests occurred in areas where maximum vegetation height was $<0.5 \mathrm{~m}$. Least Bittern nested in the broadest range of vegetation height classes, with $26 \%$ of locations as the highest frequency of nests in a single height class.

Table 2. Raw nest success values by species during May-August 2013-2019 at Emiquon Preserve, Fulton County, Illinois, USA. Success is at least one egg hatching. See Table 1 for all species scientific names.

\begin{tabular}{lcccc}
\hline \hline Species & Failures & Successes & Total & $\begin{array}{c}\text { Success } \\
\text { Rate }\end{array}$ \\
\hline American Bittern & 0 & 1 & 1 & 1.00 \\
American Coot & 22 & 25 & 47 & 0.53 \\
Black-crowned Night- & 17 & 21 & 38 & 0.55 \\
heron & & & & \\
Black-necked Stilt & 23 & 23 & 46 & 0.50 \\
Common Gallinule & 28 & 20 & 48 & 0.41 \\
Green Heron & 0 & 1 & 1 & 1.00 \\
Least Bittern & 18 & 27 & 45 & 0.60 \\
Pied-billed Grebe & 1 & 6 & 7 & 0.85 \\
Sora & 6 & 3 & 9 & 0.33 \\
\hline
\end{tabular}

Table 3. Nest success model results for each species, showing the beta estimate for the intercept, nest initiation date, and water depth, and the associated standard error from the top model for each species. See Table 1 for all species scientific names.

\begin{tabular}{lccc}
\hline \hline Species & Intercept & $\begin{array}{c}\text { Nest } \\
\text { Initiation } \\
\text { Date }\end{array}$ & Water Depth \\
\hline $\begin{array}{l}\text { Black-crowned } \\
\text { Night-Heron }\end{array}$ & $24.68 \pm 6.77$ & $-0.11 \pm 0.04$ & $-0.01 \pm 0.01$ \\
Black-necked Stilt & $11.57 \pm 3.93$ & $-0.03 \pm 0.02$ & $-0.03 \pm 0.01$ \\
Common & $11.65 \pm 3.52$ & $-0.03 \pm 0.01$ & - \\
Gallinule & & & \\
\hline
\end{tabular}

For American Coot, there were two models within $2 \triangle \mathrm{AIC}$, "Water Depth" and "Dense Emergent + Water Depth" for Common Gallinule, there were two top models within $2 \triangle \mathrm{AIC}$, "Habitat + Open Water" and "Open Water" for Least Bittern, there were two 
models within $2 \Delta \mathrm{AIC}$ "Dense Emergent Veg + Water Depth" (Appendix 4, Fig. 4). For American Coots, we found selection for water depth with a quadratic relationship $\left(\mathrm{R}_{\mathrm{m}}^{2}=0.45\right.$; Appendix 4, Fig. 4). We found Common Gallinule was more likely to nest in persistent emergent vegetation, but there was very poor model fit $\left(\mathrm{R}_{\mathrm{m}}^{2}=0.06\right.$; Appendix 5, Fig. 4). For Least Bittern, we found selection for water depth with a quadratic relationship had moderate model fit $\left(\mathrm{R}_{\mathrm{m}}^{2}=0.27\right.$; Appendix 6, Fig. 4).

Table 4. Predicted Least Bittern (Ixobrychus exilis) daily survival rate by year from nest success models during May-August 20132019 at Emiquon Preserve, Fulton County, Illinois, USA.

\begin{tabular}{lcc}
\hline \hline Year & DSR & SE \\
\hline 2013 & 0.998 & 0.733 \\
2014 & 1.000 & 1.000 \\
2015 & 0.996 & 0.644 \\
2016 & 0.992 & 0.586 \\
2017 & 1.000 & 0.731 \\
2018 & 0.996 & 0.673 \\
2019 & 1.000 & 1.000 \\
\hline
\end{tabular}

Fig. 3. Proportional frequency of occurrence of marsh bird nests by the maximum height of vegetation class during MayAugust 2013-2019 at Emiquon Preserve, Fulton County, Illinois, USA.

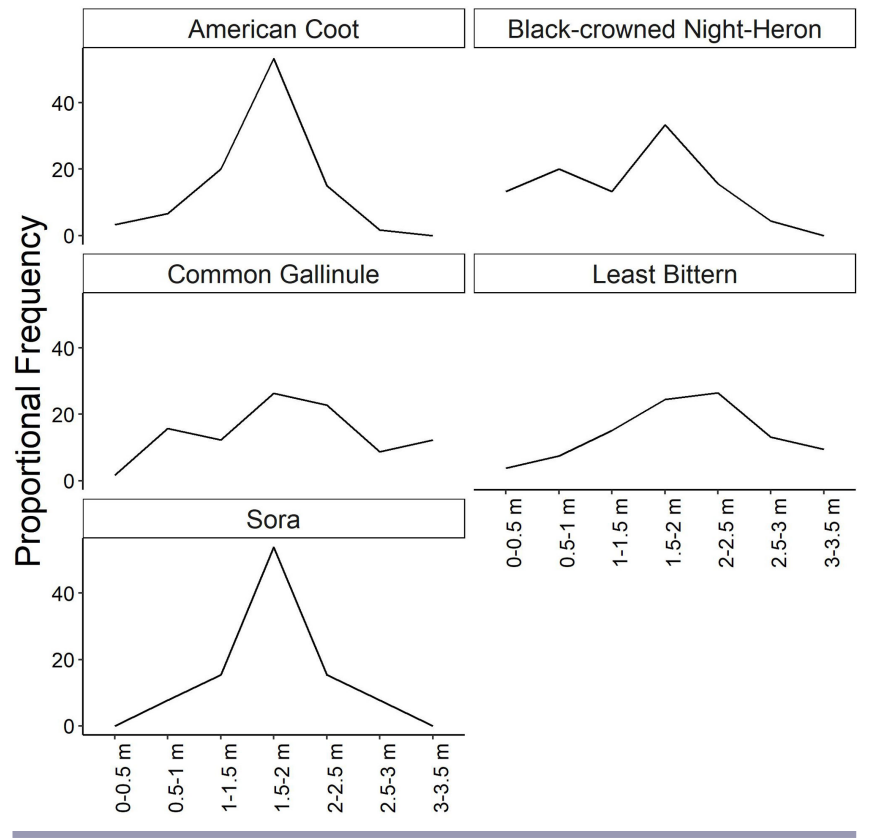

\section{Nest density and abundance}

Total nest abundance was $119(\mathrm{SE}=40$, range $=9-268)$ in hemimarsh vegetation, $253(\mathrm{SE}=89$, range $=0-647)$ in persistent emergent vegetation, and $372(\mathrm{SE}=93$, range $=215-770)$ in both emergent vegetation communities combined at Emiquon during 2013-2019. Although mean nest density differed markedly in some years, we did not find a difference in nest density between persistent emergent and hemi-marsh cover types $(\beta=0.10, \mathrm{SE}=$ $0.14, \mathrm{P}=0.48$; Fig. 5 ), and model fit was poor (Multiple $\mathrm{R}$-squared $=0.04)$. Density of Least Bittern and Common Gallinule nests were greatest, followed by American Coot, Black-crowned Nightheron, Mallard, and Sora nest density (Table 5).

Fig. 4. Odds ratios from the top model of nest-site selection for nesting species found during May-August 2013-2019 at Emiquon Preserve, Fulton County, Illinois, USA.
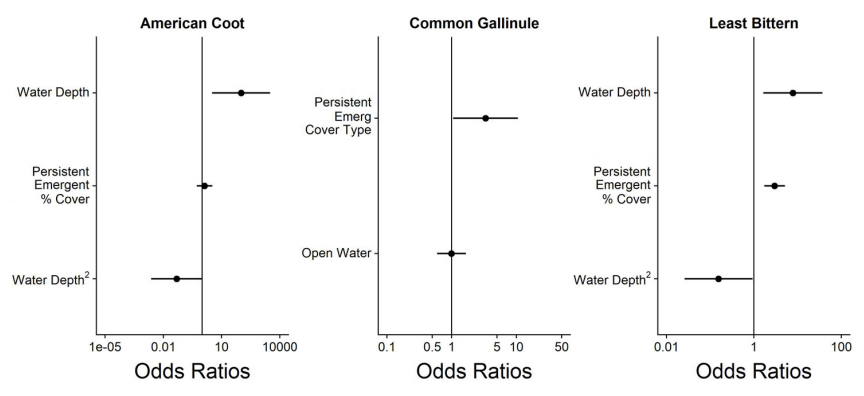

Fig. 5. Nest density of wetland birds by cover type, as well as both cover types together, found during May-August 20132019 at Emiquon Preserve, Fulton County, Illinois, USA.

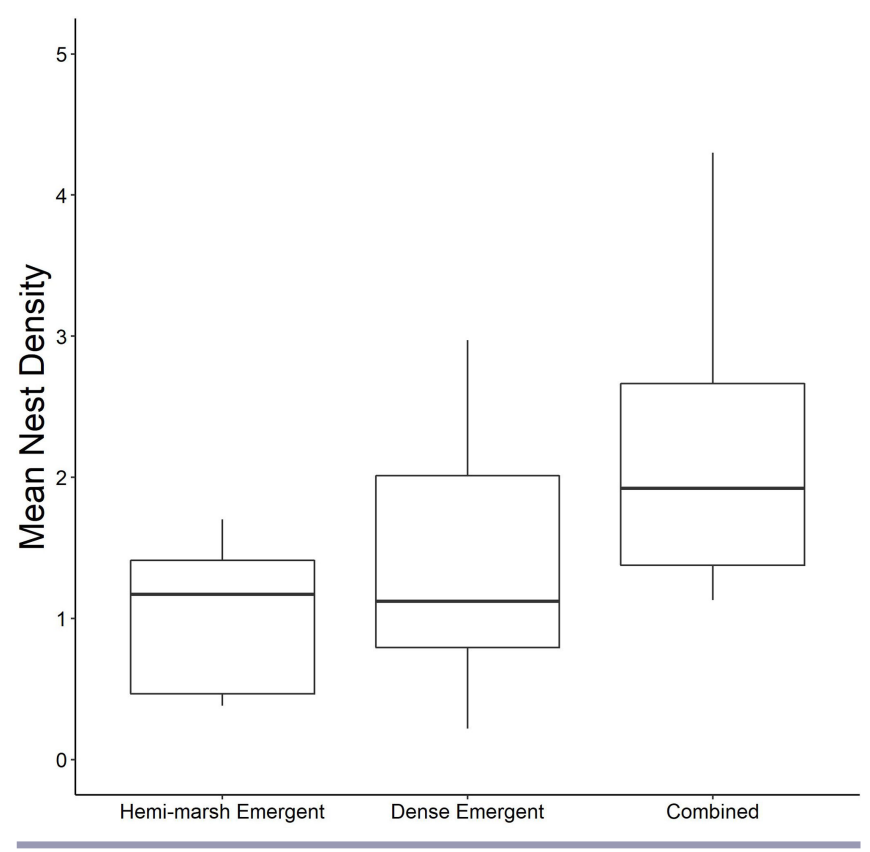

\section{DISCUSSION}

Marsh-nesting birds quickly colonized and began nesting at Emiquon following restoration (Hagy et al. 2017a). Within six years of initial flooding, more than 400 ha of persistent emergent and hemi-marsh cover types had developed as the wetland complex progressed through the marsh regeneration stage. Across 2013-2019, we estimated an average of 372 nests/year for six marsh-nesting bird species at Emiquon, but one year exceeded 770 nests. Moreover, we documented two state-endangered 
Table 5. Nest density (nest/ha), associated standard error, and results of a one-way analysis of variance among species for hemi-marsh emergent vegetation and dense emergent vegetation communities during May-August 2013-2019 at Emiquon Preserve, Fulton County, Illinois, USA.

\begin{tabular}{|c|c|c|c|c|c|c|}
\hline \multirow[t]{2}{*}{ Species } & \multicolumn{2}{|c|}{$\begin{array}{c}\text { Hemi-marsh } \\
\text { Emergent }\end{array}$} & \multicolumn{2}{|c|}{$\begin{array}{c}\text { Dense } \\
\text { Emergent } \\
\end{array}$} & \multicolumn{2}{|c|}{ Combined } \\
\hline & $\overline{\mathrm{x}}$ & SE & $\overline{\mathrm{x}}$ & $\mathrm{SE}$ & $\overline{\mathrm{x}}$ & SE \\
\hline American Coot & 0.28 & 0.07 & 0.11 & 0.07 & $0.37 \mathrm{AB}$ & 0.11 \\
\hline $\begin{array}{l}\text { Black-crowned Night- } \\
\text { heron }\end{array}$ & 0.00 & 0.00 & 0.25 & 0.23 & $0.21 \mathrm{AC}$ & 0.20 \\
\hline Common Gallinule & 0.33 & 0.16 & 0.34 & 0.27 & $0.62 \mathrm{~A}$ & 0.32 \\
\hline Least Bittern & 0.25 & 0.07 & 0.47 & 0.13 & $0.66 \mathrm{~A}$ & 0.12 \\
\hline Mallard & 0.01 & 0.01 & 0.07 & 0.07 & $0.08 \mathrm{~B}$ & 0.08 \\
\hline Sora & 0.04 & 0.04 & 0.05 & 0.05 & $0.09 \mathrm{~B}$ & 0.06 \\
\hline Unknown & 0.09 & 0.07 & 0.12 & 0.07 & 0.18 & 0.13 \\
\hline Total & $\begin{array}{c}1.00 \\
F=2.23\end{array}$ & $\begin{array}{c}0.21 \\
p=0.072\end{array}$ & 1.41 & 0.42 & 2.20 & 0.42 \\
\hline
\end{tabular}

(Common Gallinule and Black-crowned Night-Heron) and one state-threatened (Least Bittern) species nesting in multiple years of our study, indicating that wetlands restored from agricultural fields can quickly provide critical breeding habitat for birds of conservation concern. However, the progression of the marsh cycle affected the available nesting habitat and changed the marsh bird community over time.

Although species composition changed temporally, Emiquon has been able to support a diverse avian community, although the exact relationship between management to set back succession in the marsh cycle and nest success or density are complicated and still not well understood. We observed the full marsh cycle at Emiquon. In the later years of that time, we observed a shift in nesting wetland birds toward open water and hemi-marsh specialists, such as Pied-billed Grebe and American Coot (Muller and Storer 1999, Brisbin and Mowbray 2020), and overall density declined as the marsh transitioned into a lake phase by 2016 . As management actions, i.e., summer drawdowns, were enacted in 2018 and 2019 to reset the marsh cycle, i.e., dry marsh phase, persistent emergent vegetation increased, which led to a proportional increase in Least Bittern and American Coot nests and a decrease in Common Gallinule nests, similar to composition in 2013 during the regenerating marsh phase.

Our study also provides essential information on nest-site selection for a suite of marsh-nesting birds where information is extremely scant. American Coot and Sora primarily nested in Typha spp. that was $1.5-2.0 \mathrm{~m}$ in height and flooded. However, Least Bittern and Common Gallinule nested in a broader range of height classes (1.0-3.0 m), and nest success of Least Bittern was substantially higher in Typha spp. reaching $1.5-2.5 \mathrm{~m}$ than other classes. Black-crowned Night-Heron primarily nested in 1.5-2.0 m tall vegetation, but they also commonly nested across a range of height classes $(0.5-3.0 \mathrm{~m})$. In contrast, Black-necked Stilt nested in open areas with little to no emergent vegetation, such as detritus mats, old and isolated muskrat lodges, and open ditch banks and spoil piles. Similarly, Pied-billed Grebe mostly nested on floating mats of aquatic vegetation (primarily
Potamogeton nodosus) that occurred in open water areas around the perimeter of wetlands or where storms caused the vegetation to windrow. In fact, we encountered many more Pied-billed Grebe nests than we recorded, but their occurrence on floating mats meant that they occasionally moved, and repeated monitoring was difficult. In several years during the late phase (e.g., 20152017), we suspected that there were hundreds of Pied-billed Grebe nests at Emiquon Preserve each year.

American Coot and Common Gallinule commonly nested on floating or anchored platforms constructed of cattail near the water's surface, although Common Gallinule nests were typically higher off the water than American Coot. Nests of both species often occurred in persistent emergent or hemi-marsh cover types near the transition to open water. American Coots are known to be associated with more open water throughout the annual cycle, especially compared to other marsh birds (Murkin et al. 1997). Water depth at nesting sites tended to be greatest for American Coot and Pied-billed Grebe $(>1 \mathrm{~m})$, but depth was similar $(\sim 0.5$ $\mathrm{m})$ for most other overwater nesting species. Least Bittern nested substantially higher off the water than all other species, and they primarily constructed nests of woven Typha spp. under a dense coverage of Typha spp. above the nest. Least Bittern, Sora, and Black-crowned Night-Heron all tended to nest in the denser stands of emergent vegetation than American Coot or Common Gallinule. Anecdotally, we noticed that dry areas with persistent emergent vegetation rarely contained nests of any species. In several years, changing water levels created large areas of unflooded Typha spp. that were included in our search area, and we detected very few nests in dry areas. As has been previously hypothesized (Lokemoen and Woodward 1993, Albrecht et al. 2006), flooding likely dissuades mammalian predators, and that is consistent with our anecdotal observations in several years of the study when large areas of unflooded tall Typha spp. were available for nesting but unused, especially by species such as Sora and Least Bittern that build nests high in the canopy.

Migratory birds often initiate the breeding season to match the seasonally available resources, which may explain why later nests 
were less likely to succeed (Berthold et al. 2003). It is also possible that later nests are renesting attempts by pairs who failed the first time and may not be making successful choices. Nest success may also be related to changes in habitat and protection from the elements or predators and increased daily temperatures later in the summer (Borgmann et al. 2013, DeGregorio et al. 2014). Future work to understand the possible drivers is important because some factors will shift with climate change, and some are within our ability to manipulate through management. Water depth is also important in relation to nest success, either because lower water levels increase access to predators or decrease feeding access, and further work is needed to understand what role changes in water depth play in success. For instance, is water depth at a particular stage in the nesting process especially important, or is it the changing of water depth over time? Perhaps there is a depth threshold below which survival decreases markedly.

Assessing the success of restoration activities is always challenging because there are frequently multiple objectives, some of which are difficult to evaluate (Hagy et al. 2017b, Lemke et al. $2017 c$ ). Often metrics such as bird use are used as proxies for ecosystem health and recovery, with success, depending on the size of the site and the surrounding landscape (Ortega-Álvarez and Lindig-Cisneros 2012, Hagy et al. 2017b). But avian community response may change over time, as the wetland restoration project goes through the marsh cycle (VanReesSiewert and Dinsmore 1996). Restored wetlands can have less diverse plant communities and less diversity of horizontal and vertical structure, both of which can limit avian species richness, as well as the presence of nest parasites (Delphey and Dinsmore 1993, Brown and Smith 1998). Emiquon continues to be an important complex within the Illinois River Valley, providing habitat annually for dozens of species of migratory waterfowl and other wetland birds (Hagy et al. 2017a, b), while also supporting diverse fisheries and other organisms (Lemke et al. 2017d, VanMiddlesworth et al.2017a, $b$ ). The work of restoration is never complete, and as Emiquon continues to be cared for and managed, we look forward to growing our understanding of how wetland restoration in a drastically altered floodplain can support a diverse wetland community.

Despite having seven years of data, there is need for longer term data collection. A restored system like Emiquon is variable, both in the conditions the system experiences such as climate and management and in how the vegetation and birds respond to those conditions. To fully understand how the nesting wetland birds of Emiquon respond to setting back the marsh cycle or other management actions, more information is needed. In addition, we need to consider other measures of reproductive success because our method of focusing only on hatching may be too restrictive, especially for some of our study species who have highly precocial young (American Coot, Common Gallinule, among others; Bannor and Kiviat 2020, Brisbin and Mowbray 2020). Furthermore variables we did not measure may be essential parts of this larger puzzle, including duration of water level changes, and how changes in the marsh cycle influenced the predator composition, predator density, and perhaps even predator breeding success. Daily high temperatures and the frequency of heavy rain events may also be important and were not incorporated into our analysis.
Wetlands provide vitally important habitat resources for a suite of specialized plants and animals. In landscapes where most wetlands have been destroyed, like the Illinois River Valley, wetlands are also important for the services offered to people in terms of water quality improvements and floodwater storage. Wetland Restoration projects like Emiquon provide vast areas of emergent wetland vegetation that is scarce in the Illinois River Valley and the agriculturally dominated Midwest. These restored wetlands serve a wide variety of species, and so having a matrix of habitats at different stages of the marsh cycle sustains a diverse community. Because of the increasingly flashy nature of the Illinois River (where the river rises to flood stage quickly) in response to changes in precipitation patterns partly due to climate change (Sparks et al. 1998, Yetter et al. 2018), sites without sufficient protection from the river may have emergent vegetation communities destroyed before birds can successfully reproduce. The restoration of previously farmed land has tremendous potential to provide habitat for a multitude of wetland-dependent species, especially in landscapes without alternative habitat resources.

Responses to this article can be read online at: https://www.ace-eco.org/issues/responses.php/1782

\section{Acknowledgments:}

We thank the Illinois Natural History Survey and the University of Illinois at Urbana-Champaign, National Great River Research and Education Center, Illinois Ornithological Society, The Nature Conservancy, and Bob and Karen Fisher for funding. This work was supported in part through internships provided by the National Great Rivers Research \& Education Center through grant \#NGRRECIP2019-05. We thank the staff, technicians, and volunteers at the Forbes Biological Station who helped over the course of this project, including Michelle Horath, Kristen Finch, Sarah McClain, Doug McClain, Jeff Benjamin, Sam Klimas, Cheyenne Beach, Josh Osborn, Andy Gilbert, Margaret Gross, Greg Fretueg, Jacob Lux, Fletcher O'hara, Seth Owens, Dallas Glazik, Jacob Yetter, Krista Hardy, Lythande Singleton, Mallory Shaw, and Molly Jugovic. Thanks to The Nature Conservancy for access to Emiquon Preserve.

\section{LITERATURE CITED}

Albrecht, T., D. Hořák, J. Kreisinger, K. Weidinger, P. Klvaňa, and T. C. Michot. 2006. Factors determining pochard nest predation along a wetland gradient. Journal of Wildlife Management 70:784-791. https://doi.org/10.2193/0022-541X (2006)70[784:FDPNPA]2.0.CO;2

Austin, J., and D. Buhl. 2011. Nest survival of American Coots relative to grazing, burning, and water depths. Avian Conservation and Ecology 6(2):1. https://doi.org/10.5751/ACE-00472-060201

Bannor, B. K., and E. Kiviat. 2020. Common Gallinule (Gallinula galeata). Version 1.0. In A. F. Poole and F. B. Gill, editors. Birds of the world. Cornell Lab of Ornithology, Ithaca, New York, USA. https://doi.org/10.2173/bow.comgal1.01 
Bates, D., M. Mächler, B. Bolker, and S. Walker. 2015. Fitting linear mixed-effects models using lme4. Journal of Statistical Software 67:1-48. https://doi.org/10.18637/jss.v067.i01

Bellrose, F. C., S. P. Havera, F. L. Paveglio, and D. W. Steffeck. 1983. The fate of lakes in the Illinois River Valey. Illinois Natural History Survey, Champaign, Illinois, USA.

Berthold, P., E. Gwinner, and E. Sonnenschein. 2003. Avian migration. Springer, Berlin, Germany. https://doi.

org/10.1007/978-3-662-05957-9

Blake-Bradshaw, A. G. 2018. Wetland suitability for waterbirds in Illinois. University of Illinois at Uraban-Champaign, Havana, Illinois, USA.

Borgmann, K. L., C. J. Conway, and M. L. Morrison. 2013. Breeding phenology of birds: mechanisms underlying seasonal declines in the risk of nest predation. PLOS ONE 8:e65909. https:// doi.org/10.1371/journal.pone.0065909

Bowyer, M. W., J. D. Stafford, A. P. Yetter, C. S. Hine, M. M. Horath, and S. P. Havera. 2005. Moist-soil plant seed production for waterfowl at Chautauqua National Wildlife Refuge, Illinois. American Midland Naturalist 154(2):331-341. https://doi. org/10.1674/0003-0031(2005)154[0331:MPSPFW]2.0.CO;2

Bradshaw, T. M., A. G. Blake-Bradshaw, A. M. V. Fournier, J. D. Lancaster, J. O'Connell, C. N. Jacques, M. W. Eicholtz, and H. M. Hagy. 2020. Marsh bird occupancy of wetlands managed for waterfowl in the Midwestern USA - Analysis Inputs. University of Illinois at Urbana-Champaign, Havana, Illinois, USA. https:// doi.org/10.13012/B2IDB-5152821_V1

Brisbin Jr., I. L., and T. B. Mowbray. 2020. American Coot (Fulica americana). Version 1.0. In A. F. Poole and F. B. Gill, editors. Birds of the world. Cornell Lab of Ornithology, Ithaca, New York, USA. https://doi.org/10.2173/bow.y00475.01

Brown, S. C., and C. R. Smith. 1998. Breeding season bird use of recently restored versus natural wetlands in New York. Journal of Wildife Management 62:1480-1491. https://doi.org/10.2307/3802014

Conway, C. J. 2011. Standardized North American marsh bird monitoring protocol. Waterbirds 34(3):319-346. https://doi. org/10.1675/063.034.0307

Darrah, A. J., and D. G. Krementz. 2009. Distribution and habitat use of King Rails in the Illinois and Upper Mississippi River Valleys. Journal of Wildlife Management 73:1380-1386. https:// doi.org/10.2193/2008-561

Darrah, A. J., and D. G. Krementz. 2010. Occupancy and habitat use of the Least Bittern and Pied-Billed Grebe in the Illinois and Upper Mississippi River Valleys. Waterbirds 33:367-375. https:// doi.org/10.1675/063.033.0314

Darrah, A. J., and D. G. Krementz. 2011. Habitat use of nesting and brood-rearing King Rails in the Illinois and Upper Mississippi River Valleys. Waterbirds 34:160-167. https://doi. org/10.1675/063.034.0204

DeGregorio, B. A., S. J. Chiavacci, P. J. Weatherhead, J. D. Willson, T. J. Benson, and J. H. Sperry. 2014. Snake predation on North American bird nests: culprits, patterns and future directions. Journal of Avian Biology 45:325-333. https://doi. org/10.1111/jav.00364

Delphey, P. J., and J. J. Dinsmore. 1993. Breeding bird communities of recently restored and natural prairie potholes. Wetlands 13:200-206. https://doi.org/10.1007/BF03160881

Fournier, A. M. V., D. C. Mengel, E. Gbur, A. Raedeke, and D. G. Krementz. 2019. Evaluating tradeoffs in the response of Sora (Porzana carolina) and waterfowl to the timing of early autumn wetland inundation. Waterbirds 42:168-178. https://doi. org/10.1675/063.042.0203

Fournier, A. M. V., D. C. Mengel, and D. G. Krementz. 2017. Virginia and Yellow Rail autumn migration ecology: synthesis using multiple data sets. Animal Migration 4:15-22. https://doi. org/10.1515/ami-2017-0003

Fournier, A. M. V., D. C. Mengel, and D. G. Krementz. 2018. Sora (Porzana carolina) autumn migration habitat use. Royal Society Open Science 5:171664. https://doi.org/10.1098/ rsos. 171664

Fredrickson, L. H., and T. S. Taylor. 1982. Management of seasonally flooded impoundments for wildlife. U.S. Fish and Wildlife Service, U.S. Department of the Interior, Washington, D.C., USA.

Hagy, H. M., C. S. Hine, M. M. Horath, A. P. Yetter, R. V. Smith, and J. D. Stafford. 2017a. Waterbird response indicates floodplain wetland restoration. Hydrobiologia 804:119-137. https://doi. org/10.1007/s10750-016-3004-3

Hagy, H. M., M. M. Horath, A. P. Yetter, C. S. Hine, and R. V. Smith. 2017b. Evaluating tradeoffs between sanctuary for migrating waterbirds and recreational opportunities in a restored wetland complex. Hydrobiologia 804:103-118. https://doi. org/10.1007/s10750-016-2711-0

Harms, T. M., and S. J. Dinsmore. 2013. Habitat associations of secretive marsh birds in Iowa. Wetlands 33:561-571. https://doi. org/10.1007/s13157-013-0414-0

Hill, E. B. 2015. Linking wetland management decisions to secretive marsh bird habitat use during spring migration and summer breeding on public wetlands in Missouri. Thesis. University of MissouriColumbia, Missouri, USA.

Hine, C. S., H. M. Hagy, M. M. Horath, A. P. Yetter, R. V. Smith, and J. D. Stafford. 2017. Response of aquatic vegetation communities and other wetland cover types to floodplain restoration at Emiquon Preserve. Hydrobiologia 804:59-71. https://doi.org/10.1007/s10750-016-2893-5

Hothem, R. L., B. E. Brussee, W. E. Davis Jr., A. Martínez-Vilalta, A. Motis, and G. M. Kirwan. 2020. Black-crowned Night-Heron (Nycticorax nycticorax). Version 1.0. In S. M. Billerman, editor. Birds of the World. Cornell Lab of Ornithology, Ithaca, New York, USA. https://doi.org/10.2173/bow.bcnher.01

Jobin, B., and J. Picman. 1997. Factors affecting predation on artificial nests in marshes. Journal of Wildlife Management 61:792-800. https://doi.org/10.2307/3802186

Johnson, P. C. D. 2014. Extension of Nakagawa \& Schielzeth's $R_{\text {GLMM }}^{2}$ to random slopes models. Methods in Ecology and Evolution 5:944-946. https://doi.org/10.1111/2041-210X.12225 
Lemke, A. M., J. R. Herkert, J. W. Walk, and K. D. Blodgett. 2017c. Application of key ecological attributes to assess early restoration of river floodplain habitats: a case study. Hydrobiologia 804:19-33. https://doi.org/10.1007/s10750-017-3261-9

Lemke, M., H. M. Hagy, A. Casper, and H. Chen. 2018. Floodplain wetland restoration along the Illinois River. Pages 79-106 in C. Lenhart and P. C. Smiley Jr, editors. Ecological restoration in the Midwest: past, present, and future. University of Iowa Press, Iowa City, Iowa. https://doi.org/10.2307/j.ctv19x59r.9

Lemke, M. J., H. M. Hagy, K. Dungey, A. F. Casper, A. M. Lemke, T. D. VanMiddlesworth, and A. Kent. 2017b. Echoes of a flood pulse: short-term effects of record flooding of the Illinois River on floodplain lakes under ecological restoration. Hydrobiologia 804:151-175. https://doi.org/10.1007/s10750-017-3220-5

Lemke, M. J., S. F. Paver, K. E. Dungey, L. F. M. Velho, A. D. Kent, L. C. Rodrigues, D. M. Kellerhals, and M. R. Randle. 2017d. Diversity and succession of pelagic microorganism communities in a newly restored Illinois River floodplain lake. Hydrobiologia 804:35-58. https://doi.org/10.1007/s10750-017-3327-8

Lemke, M. J., J. W. Walk, A. M. Lemke, R. E. Sparks, and K. D. Blodgett. 2017a. Introduction: the ecology of a river floodplain and the Emiquon Preserve. Hydrobiologia 804:1-17. https://doi. org/10.1007/s10750-017-3335-8

Lokemoen, J. T., and R. O. Woodward. 1993. An assessment of predator barriers and predator control to enhance duck nest success on peninsulas. Wildlife Society Bulletin 21:275-282.

Lyons, J. E., M. C. Runge, H. P. Laskowski, and W. L. Kendall. 2008. Monitoring in the context of structured decision-making and adaptive management. Journal of Wildlife Management 72:1683-1692. https://doi.org/10.2193/2008-141

McClain, S. E., H. M. Hagy, C. S. Hine, A. P. Yetter, C. N. Jacques, and J. W. Simpson. 2019. Energetic implications of floodplain wetland restoration strategies for waterfowl. Restoration Ecology 27:168-177. https://doi.org/10.1111/rec.12818

Melvin, S. M., and J. P. Gibbs. 2020. Sora (Porzana carolina). Version 1.0. In A. F. Poole, editor. Birds of the world. Cornell Lab of Ornithology, Ithaca, New York, USA. https://doi.org/10.2173/ bow.sora.01

Monfils, M. J., D. B. Hayes, M. Al-Saffar, G. J. Soulliere, and R. Pierce. 2020. Marsh bird population estimates to inform conservation decisions in the Midwest. MNFI Report Number 2020-03. Michigan State University, Lansing, Michigan, USA.

Muller, M. J., and R. W. Storer. 1999. Pied-billed Grebe (Podilymbus podiceps). Version 2.0. In A. F. Poole and F. B. Gill, editors. The birds of North America. Cornell Lab of Ornithology, Ithaca, New York, USA. https://doi.org/10.2173/bna.410

Murkin, H. R., E. J. Murkin, and J. P. Ball. 1997. Avian habitat selection and prairie wetland dynamics: a 10-year experiment. Ecological Applications 7:1144-1159. https://doi.org/10.1890/1051-0761 (1997)007[1144:AHSAPW]2.0.CO;2

Nakagawa, S., and H. Schielzeth. 2013. A general and simple method for obtaining $R^{2}$ from generalized linear mixed-effects models. Methods in Ecology and Evolution 4:133-142. https://doi. org/10.1111/j.2041-210x.2012.00261.x
Ortega-Álvarez, R., and R. Lindig-Cisneros. 2012. Feathering the scene: the effects of ecological restoration on birds and the role birds play in evaluating restoration outcomes. Ecological Restoration 30:116-127. https://doi.org/10.3368/er.30.2.116

Osborn, J. M., C. S. Hine, A. P. Yetter, and A. M. V. Fournier. 2020. Monitoring of key ecological attributes and indicators of waterbirds at the Nature Conservancy's Emiquon Preserve: annual report 2019. Prairie Research Institute, Illinois Natural History Survey, Champaign, Illinois, USA.

Picman, J., M. L. Milks, and M. Leptich. 1993. Patterns of predation on passerine nests in marshes: effects of water depth and distance from edge. Auk 110:89-94. https://doi.org/10.1093/ auk/110.1.89

Poole, A. F., P. E. Lowther, J. P. Gibbs, F. A. Reid, and S. M. Melvin. 2020. Least Bittern (Ixobrychus exilis). Version 1.0. In A. F. Poole, editor. Birds of the world. Cornell Lab of Ornithology, Ithaca, New York, USA. https://doi.org/10.2173/bow.leabit.01

R Core Team. 2019. R: A language and environment for statistical computing. R Foundation for Statistical Computing, Vienna, Austria.

Sayre, M. W., and W. D. Rundle. 1984. Comparison of habitat use by migrant Soras and Virginia Rails. Journal of Wildlife Management 48:599-605. https://doi.org/10.2307/3801198

Shaffer, T. L. 2004. A unified approach to analyzing nest success. Auk 121:526-540. https://doi.org/10.1642/0004-8038(2004)121 [0526:AUATAN]2.0.CO;2

Sparks, R. E., J. C. Nelson, and Y. Yin. 1998. Naturalization of the flood regime in regulated rivers: the case of the upper Mississippi River. BioScience 48:706-720. https://doi.org/10.2307/1313334

van der Valk, A. G., and C. B. Davis. 1978. The role of seed banks in the vegetation dynamics of prairie glacial marshes. Ecology 59:322-335. https://doi.org/10.2307/1936377

VanMiddlesworth, T. D., N. N. McClelland, G. G. Sass, A. F. Casper, T. W. Spier, and M. J. Lemke. 2017a. Fish community succession and biomanipulation to control two common aquatic ecosystem stressors during a large-scale floodplain lake restoration. Hydrobiologia 804:73-88. https://doi.org/10.1007/ s10750-016-2696-8

VanMiddlesworth, T. D., G. G. Sass, B. A. Ray, T. W. Spier, J. D. Lyons, N. N. McClelland, and A. F. Casper. 2017b. Food habits and relative abundances of native piscivores: implications for controlling common carp. Hydrobiologia 804:89-101. https://doi. org/10.1007/s10750-016-2866-8

VanRees-Siewert, K. L., and J. J. Dinsmore. 1996. Influence of wetland age on bird use of restored wetlands in Iowa. Wetlands 16:577-582. https://doi.org/10.1007/BF03161348

Weller, M. W., and L. H. Fredrickson. 1973. Avian ecology of a managed glacial marsh. Living Bird 12:269-291.

Westerkov, K. 1950. Methods for determining the age of game bird eggs. Journal of Wildlife Management 14:56-67. https://doi. org/10.2307/3795978

Wilson, E. D., W. E. Jensen, and R. Schultheis. 2018. Habitat use by secretive marsh birds during spring and fall migration in moist- 
soil wetlands in Kansas. Wilson Journal of Ornithology 130:385-396. https://doi.org/10.1676/16-215.1

Yetter, A. P., H. M. Hagy, M. M. Horath, J. D. Lancaster, C. S. Hine, R. V. Smith, and J. D. Stafford. 2018. Mallard survival, movements, and habitat use during autumn in Illinois. Journal of Wildlife Management 82:182-191. https://doi.org/10.1002/ jwmg. 21346

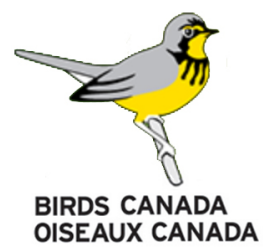


Appendix 1. Mean, standard error and change, by species and covariate, for failed nests, successful nests and all nests.

\begin{tabular}{|c|c|c|c|c|c|c|c|c|c|c|c|c|c|c|c|c|c|c|c|c|}
\hline \multirow{2}{*}{ Species } & \multirow{2}{*}{ Fate } & \multicolumn{3}{|c|}{ Nest Height } & \multicolumn{3}{|c|}{ Water Depth } & \multicolumn{3}{|c|}{ Secchi Depth } & \multicolumn{3}{|c|}{ Dense Emergent } & \multicolumn{3}{|c|}{ Clutch Size } & \multicolumn{3}{|c|}{ Initiation Date } & \multirow{2}{*}{$n$} \\
\hline & & $\mathrm{x}$ & SE & $\Delta$ & $\mathrm{x}$ & SE & $\Delta$ & $\mathrm{x}$ & SE & $\Delta$ & $\mathrm{x}$ & $\mathrm{SE}$ & $\Delta$ & $\mathrm{x}$ & SE & $\Delta$ & $\mathrm{x}$ & SE & $\Delta$ & \\
\hline \multirow{3}{*}{$\begin{array}{l}\text { American } \\
\text { Bittern }\end{array}$} & Failure & -- & -- & & -- & -- & & -- & -- & & -- & -- & & -- & -- & & 3-Jun & -- & & -- \\
\hline & Success & -- & -- & -- & 58.0 & 0.0 & -- & 35.0 & 0.0 & -- & 60.0 & 0.0 & -- & 1.0 & -- & -- & 3-Jun & -- & -- & 1 \\
\hline & Total & -- & -- & & 58.0 & 0.0 & & 35.0 & 0.0 & & 60.0 & 0.0 & & 1.0 & -- & & & -- & & 1 \\
\hline \multirow{3}{*}{$\begin{array}{c}\text { American } \\
\text { Coot }\end{array}$} & Failure & 5.8 & 1.9 & & 108.6 & 8.7 & & 69.4 & 8.2 & & 46.7 & 4.1 & & 3.8 & 0.4 & & 27-Jun & 2.3 & & 27 \\
\hline & Success & 4.1 & 1.7 & $-41.1 \%$ & 124.3 & 7.2 & $12.6 \%$ & 91.7 & 8.4 & $24.3 \%$ & 53.5 & 4.5 & $12.7 \%$ & 4.7 & 0.4 & $17.5 \%$ & 24-Jun & 2.5 & 0.0 & 29 \\
\hline & Total & 5.5 & 1.2 & & 113.0 & 5.4 & & 77.9 & 5.7 & & 48.2 & 3.0 & & 4.3 & 0.3 & & 25-Jun & 1.7 & & 61 \\
\hline \multirow{3}{*}{$\begin{array}{l}\text { Black- } \\
\text { crowned } \\
\text { Night- } \\
\text { heron }\end{array}$} & Failure & 9.5 & 5.6 & & 62.1 & 4.1 & & 26.1 & 2.5 & & 82.1 & 1.8 & & 3.2 & 0.2 & & 6-Jun & 1.9 & & 19 \\
\hline & Success & 7.7 & 2.4 & $-24.0 \%$ & 64.0 & 3.3 & $3.1 \%$ & 35.5 & 3.6 & $26.5 \%$ & 79.8 & 3.3 & $-2.9 \%$ & 2.8 & 0.3 & $-15.8 \%$ & 28-May & 2.6 & -0.1 & 22 \\
\hline & Total & 9.3 & 2.8 & & 63.7 & 2.4 & & 30.8 & 2.2 & & 81.8 & 1.9 & & 3.0 & 0.2 & & 1-Jun & 1.8 & & 45 \\
\hline \multirow{3}{*}{$\begin{array}{c}\text { Black- } \\
\text { necked } \\
\text { Stilt }\end{array}$} & Failure & 0.8 & 0.4 & & 18.2 & 5.7 & & 14.5 & 4.5 & & 8.3 & 5.2 & & 3.3 & 0.2 & & 5-Jun & 2.3 & & 24 \\
\hline & Success & 0.2 & 0.2 & $-235.2 \%$ & 2.1 & 1.5 & $-772.3 \%$ & 2.1 & 1.5 & $-592.3 \%$ & 4.3 & 3.9 & $-91.7 \%$ & 3.6 & 0.2 & $8.8 \%$ & 2-Jun & 1.9 & 0.0 & 23 \\
\hline & Total & 0.5 & 0.2 & & 9.8 & 3.1 & & 8.0 & 2.5 & & 6.3 & 3.2 & & 3.4 & 0.1 & & 4-Jun & 1.5 & & 48 \\
\hline \multirow{3}{*}{$\begin{array}{l}\text { Common } \\
\text { Gallinule }\end{array}$} & Failure & 30.4 & 7.8 & & 60.6 & 6.7 & & 41.0 & 5.6 & & 47.3 & 5.4 & & 4.8 & 0.5 & & 18-Jun & 2.9 & & 28 \\
\hline & Success & 38.9 & 9.0 & $21.9 \%$ & 63.6 & 6.0 & $4.6 \%$ & 39.3 & 5.6 & $-4.3 \%$ & 60.4 & 5.1 & $21.7 \%$ & 6.8 & 0.6 & $29.6 \%$ & 4-Jun & 2.5 & -0.1 & 24 \\
\hline & Total & 33.0 & 5.3 & & 64.9 & 4.4 & & 41.9 & 4.0 & & 52.2 & 3.5 & & 5.8 & 0.4 & & 11-Jun & 2.1 & & 58 \\
\hline \multirow{3}{*}{$\begin{array}{l}\text { Green } \\
\text { Heron }\end{array}$} & Failure & -- & -- & & -- & -- & & -- & -- & & -- & -- & & -- & -- & & 25-May & -- & & -- \\
\hline & Success & -- & -- & -- & 92.0 & 0.0 & -- & 30.0 & 0.0 & -- & 50.0 & 0.0 & -- & 4.0 & -- & -- & 25-May & -- & 0.0 & 1 \\
\hline & Total & -- & -- & & 92.0 & -- & & 30.0 & -- & & 50.0 & -- & & 4.0 & -- & & & -- & & 1 \\
\hline \multirow{3}{*}{$\begin{array}{l}\text { Least } \\
\text { Bittern }\end{array}$} & Failure & 59.5 & 8.6 & & 60.9 & 8.9 & & 48.6 & 9.2 & & 66.3 & 4.9 & & 2.6 & 0.4 & & 15-Jun & 2.8 & & 17 \\
\hline & Success & 58.8 & 5.6 & $-1.2 \%$ & 61.1 & 6.1 & $0.3 \%$ & 40.9 & 6.8 & $-18.7 \%$ & 71.7 & 3.4 & $7.6 \%$ & 3.4 & 0.3 & $21.3 \%$ & 13-Jun & 2.6 & 0.0 & 33 \\
\hline & Total & 59.5 & 4.4 & & 64.8 & 5.2 & & 44.0 & 5.2 & & 70.3 & 2.6 & & 3.1 & 0.3 & & 14-Jun & 1.9 & & 54 \\
\hline \multirow{3}{*}{ Mallard } & Failure & 0.0 & 0.0 & & 13.9 & 8.4 & & 6.5 & 4.5 & & 43.1 & 8.2 & & 6.1 & 0.5 & & 1-Jun & 3.5 & & 18 \\
\hline & Success & 0.0 & 0.0 & -- & 11.0 & 9.2 & $-26.4 \%$ & 6.6 & 5.5 & $1.1 \%$ & 28.1 & 12.3 & $-53.1 \%$ & 6.7 & 0.7 & $9.6 \%$ & 1-Jun & 5.6 & 0.0 & 10 \\
\hline & Total & 0.0 & 0.0 & & 17.9 & 7.4 & & 10.9 & 5.2 & & 37.2 & 6.7 & & 6.3 & 0.4 & & 1-Jun & 2.9 & & 29 \\
\hline Pied- & Failure & 0.0 & 0.0 & & -- & -- & & -- & -- & & 0.0 & 0.0 & & 4.0 & -- & & 15-Jul & -- & & 1 \\
\hline billed & Success & 0.0 & 0.0 & -- & 107.3 & 5.1 & -- & 80.5 & 9.6 & -- & 11.7 & 11.7 & -- & 3.3 & 1.0 & $-20.0 \%$ & 2-Jul & 4.2 & -0.1 & 6 \\
\hline Grebe & Total & 0.0 & 0.0 & & 107.1 & 4.3 & & 82.6 & 8.4 & & 10.0 & 10.0 & & 3.4 & 0.9 & & 4-Jul & 4.0 & & 7 \\
\hline
\end{tabular}




\begin{tabular}{|c|c|c|c|c|c|c|c|c|c|c|c|c|c|c|c|c|c|c|c|}
\hline Failure & 25.0 & 0.0 & & 103.9 & 23.4 & & 74.1 & 14.0 & & 55.7 & 5.4 & & 6.6 & 1.7 & & 13-Jun & 9.0 & & 7 \\
\hline Success & 23.0 & 0.0 & -- & 81.3 & 9.2 & $-27.8 \%$ & 33.0 & 8.1 & $-124.5 \%$ & 93.3 & 21.7 & $40.3 \%$ & 4.0 & 1.2 & $-64.3 \%$ & 24-Jun & 10.8 & 0.1 & 3 \\
\hline Total & 23.3 & 0.8 & & 92.7 & 13.0 & & 56.6 & 9.3 & & 67.3 & 7.6 & & 5.8 & 1.3 & & 16-Jun & 6.9 & & 13 \\
\hline
\end{tabular}


Appendix 2. AIC Tables for model sets about success of nests found during May-August 2013-2019 at Emiquon Preserve, Fulton County, Illinois, USA.

\begin{tabular}{llrrrr} 
& & & & Delta & \multicolumn{2}{l}{ AlC } \\
Species & Model Name & K & AlCc & AlCc & \multicolumn{1}{l}{ Weight } \\
All & Initiation Date + Water Depth & 3 & 365.4381 & & 0.205829 \\
All & NULL & 1 & 366.3197 & 0.881615 & 0.132454 \\
All & Initiation Date & 2 & 366.52 & 1.081898 & 0.119833 \\
All & \% Dense Emergent Veg & 2 & 366.9375 & 1.499474 & 0.097252 \\
All & Year & 7 & 367.2324 & 1.794322 & 0.083922 \\
All & Emergent Veg Height & 2 & 367.4022 & 1.964139 & 0.07709 \\
All & Water Depth & 2 & 367.4234 & 1.985307 & 0.076279 \\
All & \% Non-Persistent Emergent Veg & 2 & 367.9752 & 2.537172 & 0.057885 \\
All & \% Non-Persistent Emergent Veg + \% & & & & \\
& Aquatic Bed & 2 & 367.9752 & 2.537172 & 0.057885 \\
All & \% Open Water & 2 & 368.0449 & 2.606801 & 0.055905 \\
All & Species & 6 & 369.7268 & 4.288778 & 0.024111 \\
All & GLOBAL & 18 & 371.1978 & 5.759727 & 0.011556 \\
American Coot & Water Depth & 2 & 73.01463 & & 0.204395 \\
American Coot & Year & 5 & 74.42309 & 1.408454 & 0.101071 \\
American Coot & Initiation Date + Water Depth & 3 & 74.48444 & 1.469812 & 0.098018 \\
American Coot & NULL & 1 & 74.59223 & 1.577597 & 0.092875 \\
American Coot & \% Non-Persistent Emergent Veg & 1 & 74.59223 & 1.577597 & 0.092875 \\
American Coot & Water Depth + \% Open Water & 3 & 74.75628 & 1.741651 & 0.085561 \\
American Coot & Water Depth + Emergent Veg Height & 3 & 74.89886 & 1.884228 & 0.079674 \\
American Coot & Emergent Veg Height & 2 & 75.63794 & 2.623306 & 0.055059 \\
American Coot & Emergent Veg Height + Water Depth + & & & & \\
& \% Open Water & 4 & 75.76188 & 2.747244 & 0.05175 \\
American Coot & \% Dense Emergent Veg & 2 & 76.18901 & 3.174376 & 0.041799 \\
American Coot & \% Open Water & 2 & 76.75416 & 3.739525 & 0.03151 \\
American Coot & Initiation Date & 2 & 76.75919 & 3.744555 & 0.03143 \\
American Coot & Emergent Veg Height + \% Open Water & 3 & 77.50407 & 4.489441 & 0.021657
\end{tabular}




\begin{tabular}{|c|c|c|c|c|c|}
\hline American Coot & $\begin{array}{l}\text { Emergent Veg Height + \% Open Water + } \\
\% \text { Dense Emergent Veg }\end{array}$ & 4 & 78.79714 & 5.782512 & 0.011345 \\
\hline $\begin{array}{l}\text { American Coot } \\
\text { Common }\end{array}$ & GLOBAL & 10 & 83.69259 & 10.67796 & 0.000981 \\
\hline $\begin{array}{l}\text { Gallinule } \\
\text { Common }\end{array}$ & Initiation Date & 2 & 62.09958 & 0 & 0.559287 \\
\hline $\begin{array}{l}\text { Gallinule } \\
\text { Common }\end{array}$ & Initiation Date + Water Depth & 3 & 64.18426 & 2.084679 & 0.197221 \\
\hline $\begin{array}{l}\text { Gallinule } \\
\text { Common }\end{array}$ & \% Dense Emergent Veg & 2 & 66.3588 & 4.259216 & 0.06649 \\
\hline $\begin{array}{l}\text { Gallinule } \\
\text { Common }\end{array}$ & $\begin{array}{l}\text { NULL } \\
\text { Emergent Veg Height + \% Open Water + }\end{array}$ & 1 & 67.38911 & 5.28953 & 0.039722 \\
\hline $\begin{array}{l}\text { Gallinule } \\
\text { Common }\end{array}$ & \% Dense Emergent Veg & 4 & 67.76071 & 5.661126 & 0.032987 \\
\hline $\begin{array}{l}\text { Gallinule } \\
\text { Common }\end{array}$ & $\%$ Non-Persistent Emergent Veg & 2 & 68.24007 & 6.140483 & 0.025956 \\
\hline $\begin{array}{l}\text { Gallinule } \\
\text { Common }\end{array}$ & \% Open Water & 2 & 68.34063 & 6.241044 & 0.024684 \\
\hline $\begin{array}{l}\text { Gallinule } \\
\text { Common }\end{array}$ & Emergent Veg Height & 2 & 69.51298 & 7.413393 & 0.013735 \\
\hline $\begin{array}{l}\text { Gallinule } \\
\text { Common }\end{array}$ & Water Depth & 2 & 69.5298 & 7.430216 & 0.01362 \\
\hline $\begin{array}{l}\text { Gallinule } \\
\text { Common }\end{array}$ & Emergent Veg Height $+\%$ Open Water & 3 & 70.50143 & 8.401844 & 0.008379 \\
\hline $\begin{array}{l}\text { Gallinule } \\
\text { Common }\end{array}$ & Water Depth +\% Open Water & 3 & 70.6071 & 8.507514 & 0.007948 \\
\hline $\begin{array}{l}\text { Gallinule } \\
\text { Common }\end{array}$ & $\begin{array}{l}\text { Water Depth + Emergent Veg Height } \\
\text { Emergent Veg Height }+ \text { Water Depth }+\%\end{array}$ & 3 & 71.67187 & 9.572288 & 0.004667 \\
\hline $\begin{array}{l}\text { Gallinule } \\
\text { Common }\end{array}$ & Open Water & 4 & 72.79578 & 10.69619 & 0.002661 \\
\hline $\begin{array}{l}\text { Gallinule } \\
\text { Common }\end{array}$ & Year & 5 & 72.98672 & 10.88714 & 0.002418 \\
\hline Gallinule & GLOBAL & 11 & 77.73182 & 15.63224 & 0.000225 \\
\hline Least Bittern & Year & 7 & 56.99329 & 0 & 0.499343 \\
\hline
\end{tabular}




\begin{tabular}{|c|c|c|c|c|c|}
\hline Least Bittern & $\begin{array}{l}\text { Emergent Veg Height + \% Open Water + } \\
\% \text { Dense Emergent Veg }\end{array}$ & 4 & 60.26012 & 3.26683 & 0.097503 \\
\hline Least Bittern & $\%$ Open Water & 2 & 60.29515 & 3.301857 & 0.09581 \\
\hline Least Bittern & GLOBAL & 12 & 60.97346 & 3.98017 & 0.068252 \\
\hline Least Bittern & Emergent Veg Height $+\%$ Open Water & 3 & 61.3707 & 4.377412 & 0.055957 \\
\hline Least Bittern & Water Depth + \% Open Water & 3 & 62.37228 & 5.378991 & 0.033913 \\
\hline Least Bittern & NULL & 1 & 62.64304 & 5.649745 & 0.029619 \\
\hline Least Bittern & $\%$ Non-Persistent Emergent Veg & 1 & 62.64304 & 5.649745 & 0.029619 \\
\hline Least Bittern & $\begin{array}{l}\text { Emergent Veg Height } \\
\text { Emergent Veg Height }+ \text { Water Depth }+\%\end{array}$ & 2 & 63.3655 & 6.372205 & 0.020639 \\
\hline Least Bittern & Open Water & 4 & 63.76492 & 6.771626 & 0.016903 \\
\hline Least Bittern & \% Dense Emergent Veg & 2 & 64.18084 & 7.187546 & 0.013729 \\
\hline Least Bittern & Water Depth & 2 & 64.73076 & 7.73747 & 0.010429 \\
\hline Least Bittern & Initiation Date & 2 & 64.78158 & 7.788288 & 0.010167 \\
\hline Least Bittern & $\begin{array}{l}\text { Water Depth + Emergent Veg Height } \\
\% \text { Dense Emergent Veg + Emergent Veg }\end{array}$ & 3 & 65.40722 & 8.413928 & 0.007436 \\
\hline Least Bittern & Height & 3 & 65.49124 & 8.497951 & 0.00713 \\
\hline Least Bittern & Initiation Date + Water Depth & 3 & 66.88572 & 9.892424 & 0.00355 \\
\hline Black-necked Stilt & Initiation Date + Water Depth & 3 & 59.93441 & 0 & 0.362827 \\
\hline Black-necked Stilt & Water Depth & 2 & 60.04388 & 0.109466 & 0.343502 \\
\hline Black-necked Stilt & Water Depth + Open Water & 3 & 62.26332 & 2.328912 & 0.113236 \\
\hline Black-necked Stilt & $\begin{array}{l}\text { Water Depth }+ \text { Emergent Veg Height } \\
\text { Emergent Veg Height }+ \text { Water Depth }+\%\end{array}$ & 3 & 62.28945 & 2.355038 & 0.111766 \\
\hline Black-necked Stilt & Open Water & 4 & 64.58508 & 4.650671 & 0.035467 \\
\hline Black-necked Stilt & NULL & 1 & 67.14786 & 7.213451 & 0.009847 \\
\hline Black-necked Stilt & Initiation Date & 2 & 68.3763 & 8.441891 & 0.005328 \\
\hline Black-necked Stilt & \% Open Water & 2 & 69.01304 & 9.07863 & 0.003875 \\
\hline Black-necked Stilt & $\%$ Non-Persistent Emergent Veg & 2 & 69.20126 & 9.266849 & 0.003527 \\
\hline Black-necked Stilt & Emergent Veg Height & 2 & 69.23978 & 9.305373 & 0.00346 \\
\hline Black-necked Stilt & \% Dense Emergent Veg & 2 & 69.33429 & 9.399876 & 0.0033 \\
\hline Black-necked Stilt & Year & 5 & 70.24967 & 10.31526 & 0.002088 \\
\hline Black-necked Stilt & Emergent Veg Height + \% Open Water & 3 & 71.18728 & 11.25287 & 0.001307 \\
\hline
\end{tabular}


Emergent Veg Height + \% Open Water +

Black-necked Stilt

Black-necked Stilt

Black-crowned

Night-heron

Black-crowned

Night-heron

Black-crowned

Night-heron

Black-crowned

Night-heron

Black-crowned

Night-heron

Black-crowned

Night-heron

Black-crowned

Night-heron

Black-crowned

Night-heron

Black-crowned

Night-heron

Black-crowned

Night-heron

Black-crowned

Night-heron

Black-crowned

Night-heron

Black-crowned

Night-heron

Black-crowned

Night-heron

Black-crowned

Night-heron
GLOBAL

Initiation Date + Water Depth

Initiation Date

GLOBAL

NULL

\% Non-Persistent Emergent Veg

Year

\% Open Water

\% Dense Emergent Veg

Emergent Veg Height

Water Depth

Water Depth + Emergent Veg Height

Water Depth + \% Open Water

Emergent Veg Height + \% Open Water

Emergent Veg Height + Water Depth $+\%$

Open Water

Emergent Veg Height + \% Open Water +

$\%$ Dense Emergent Veg $\begin{array}{llll}4 & 73.59146 & 13.65705 & 0.000393\end{array}$

$\begin{array}{llll}11 & 76.8738 & 16.93939 & 7.61 \mathrm{E}-05\end{array}$

$\begin{array}{llll}3 & 49.21728 & 0 & 0.455016\end{array}$

$\begin{array}{llll}2 & 49.53263 & 0.315354 & 0.388641\end{array}$

$9 \quad 51.77981 \quad 2.562529 \quad 0.126352$

$1 \quad 57.83609 \quad 8.618807 \quad 0.006116$

$1 \quad 57.83609 \quad 8.618807 \quad 0.006116$

$\begin{array}{llll}4 & 58.50748 & 9.290202 & 0.004372\end{array}$

$\begin{array}{llll}2 & 59.45617 & 10.23889 & 0.002721\end{array}$

$\begin{array}{llll}2 & 59.67408 & 10.4568 & 0.00244\end{array}$

$\begin{array}{llll}2 & 59.87162 & 10.65434 & 0.00221\end{array}$

$2 \quad 59.88961 \quad 10.67233 \quad 0.002191$

$\begin{array}{llll}3 & 61.43297 & 12.21569 & 0.001013\end{array}$

$3 \quad 61.45263 \quad 12.23535 \quad 0.001003$

$\begin{array}{llll}3 & 61.59975 & 12.38247 & 0.000932\end{array}$

$\begin{array}{llll}4 & 62.95191 & 13.73463 & 0.000474\end{array}$

$\begin{array}{llll}4 & 63.26778 & 14.0505 & 0.000405\end{array}$ 
Appendix 3. AIC tables for model sets about nest site selection of nests found within random plots during May-August 2013-2019 at Emiquon Preserve, Fulton County, Illinois, USA.

\begin{tabular}{|c|c|c|c|c|c|}
\hline Species & Model Name & K & $\mathrm{AlCc}$ & Delta AICc & AIC Weight \\
\hline American Coot & $\begin{array}{l}\text { Water Depth } \\
\text { Dense Emergent Veg + }\end{array}$ & 4 & 76.12829 & 0 & 0.449602 \\
\hline American Coot & Water Depth & 5 & 78.1097 & 1.981404 & 0.166944 \\
\hline American Coot & $\begin{array}{l}\text { Habitat + Water Depth } \\
\text { Water Depth + }\end{array}$ & 5 & 78.27883 & 2.150537 & 0.153407 \\
\hline American Coot & Emergent Veg Height & 5 & 78.34891 & 2.220616 & 0.148125 \\
\hline American Coot & $\begin{array}{l}\text { GLOBAL } \\
\text { Emergent Veg Height + }\end{array}$ & 8 & 80.67065 & 4.542357 & 0.046395 \\
\hline American Coot & $\begin{array}{l}\text { Open Water } \\
\text { Habitat + Emergent Veg }\end{array}$ & 5 & 81.38723 & 5.258936 & 0.032424 \\
\hline American Coot & $\begin{array}{l}\text { Height + Open Water } \\
\text { Habitat + Emergent Veg }\end{array}$ & 5 & 87.95163 & 11.82334 & 0.001217 \\
\hline American Coot & Height & 4 & 89.13321 & 13.00491 & 0.000674 \\
\hline American Coot & Emergent Veg Height & 3 & 90.6081 & 14.4798 & 0.000323 \\
\hline American Coot & Open Water & 3 & 90.63062 & 14.50232 & 0.000319 \\
\hline American Coot & $\begin{array}{l}\text { Habitat + Open Water } \\
\text { Dense Emergent Veg + }\end{array}$ & 4 & 91.01711 & 14.88882 & 0.000263 \\
\hline American Coot & Emergent Veg Height & 4 & 92.59805 & 16.46976 & 0.000119 \\
\hline American Coot & Habitat & 3 & 92.80702 & 16.67873 & 0.000107 \\
\hline American Coot & NULL & 2 & 93.98133 & 17.85304 & $5.97 \mathrm{E}-05$ \\
\hline $\begin{array}{l}\text { American Coot } \\
\text { Common }\end{array}$ & Dense Emergent Veg & 3 & 96.13122 & 20.00292 & 2.04E-05 \\
\hline $\begin{array}{l}\text { Gallinule } \\
\text { Common }\end{array}$ & Habitat + Open Water & 4 & 102.1868 & 0 & 0.529626 \\
\hline Gallinule & Open Water & 3 & 104.0271 & 1.840309 & 0.211034 \\
\hline Common & Habitat + Emergent Veg & & & & \\
\hline Gallinule & Height + Open Water & 5 & 104.4245 & 2.237723 & 0.173003 \\
\hline $\begin{array}{l}\text { Common } \\
\text { Gallinule }\end{array}$ & $\begin{array}{l}\text { Emergent Veg Height + } \\
\text { Open Water }\end{array}$ & 5 & 106.3943 & 4.207502 & 0.064613 \\
\hline $\begin{array}{l}\text { Common } \\
\text { Gallinule } \\
\text { Common }\end{array}$ & GLOBAL & 8 & 108.6496 & 6.462811 & 0.020921 \\
\hline $\begin{array}{l}\text { Gallinule } \\
\text { Common }\end{array}$ & NULL & 2 & 117.639 & 15.45219 & 0.000234 \\
\hline $\begin{array}{l}\text { Gallinule } \\
\text { Common }\end{array}$ & Emergent Veg Height & 3 & 118.7697 & 16.58287 & 0.000133 \\
\hline $\begin{array}{l}\text { Gallinule } \\
\text { Common }\end{array}$ & Habitat & 3 & 119.3617 & 17.17488 & 9.87E-05 \\
\hline Gallinule & Dense Emergent Veg & 3 & 119.6051 & 17.41827 & 8.74E-05 \\
\hline Common & Habitat + Emergent Veg & & & & \\
\hline Gallinule & Height & 4 & 119.9016 & 17.71484 & 7.54E-05 \\
\hline Common & Dense Emergent Veg + & 4 & 120.0454 & 17.85856 & 7.02E-05 \\
\hline
\end{tabular}




\begin{tabular}{|c|c|c|c|c|c|}
\hline Gallinule & Emergent Veg Height & & & & \\
\hline Common & & & & & \\
\hline Gallinule & Water Depth & 4 & 121.1462 & 18.95944 & 4.05E-05 \\
\hline Common & Water Depth + & & & & \\
\hline Gallinule & Emergent Veg Height & 5 & 121.5581 & 19.37125 & $3.29 \mathrm{E}-05$ \\
\hline Common & Habitat + Emergent Veg & & & & \\
\hline Gallinule & Height & 5 & 122.9443 & 20.75749 & $1.65 \mathrm{E}-05$ \\
\hline Common & Dense Emergent Veg + & & & & \\
\hline Gallinule & $\begin{array}{l}\text { Water Depth } \\
\text { Dense Emergent Veg + }\end{array}$ & 5 & 123.2075 & 21.02067 & $1.44 \mathrm{E}-05$ \\
\hline Least Bittern & Water Depth & 5 & 163.0529 & 0 & 0.770047 \\
\hline Least Bittern & GLOBAL & 8 & 166.5927 & 3.539787 & 0.131178 \\
\hline Least Bittern & $\begin{array}{l}\text { Dense Emergent Veg } \\
\text { Dense Emergent Veg + }\end{array}$ & 3 & 167.9442 & 4.891319 & 0.066739 \\
\hline Least Bittern & Emergent Veg Height & 4 & 169.4815 & 6.428575 & 0.030944 \\
\hline Least Bittern & Habitat + Water Depth & 5 & 177.6219 & 14.56903 & 0.000528 \\
\hline Least Bittern & Habitat & 3 & 179.7071 & 16.65414 & 0.000186 \\
\hline Least Bittern & $\begin{array}{l}\text { Water Depth } \\
\text { Habitat + Emergent Veg }\end{array}$ & 4 & 181.384 & 18.33106 & $8.05 E-05$ \\
\hline Least Bittern & Height & 4 & 181.6537 & 18.60083 & 7.04E-05 \\
\hline Least Bittern & Habitat + Open Water & 4 & 181.7888 & 18.73585 & $6.58 \mathrm{E}-05$ \\
\hline Least Bittern & NULL & 2 & 182.4838 & 19.43086 & 4.65E-05 \\
\hline Least Bittern & $\begin{array}{l}\text { Water Depth }+ \\
\text { Emergent Veg Height }\end{array}$ & 5 & 182.9553 & 19.90242 & 3.67E-05 \\
\hline Least Bittern & $\begin{array}{l}\text { Open Water } \\
\text { Habitat + Emergent Veg }\end{array}$ & 3 & 183.6842 & 20.63124 & $2.55 \mathrm{E}-05$ \\
\hline Least Bittern & Height + Open Water & 5 & 183.7516 & 20.69867 & 2.47E-05 \\
\hline Least Bittern & $\begin{array}{l}\text { Emergent Veg Height } \\
\text { Emergent Veg Height + }\end{array}$ & 3 & 183.8709 & 20.818 & $2.32 \mathrm{E}-05$ \\
\hline Least Bittern & Open Water & 5 & 187.1973 & 24.14437 & 4.40E-06 \\
\hline
\end{tabular}


Appendix 4. Model results from the Persistent Emergent Veg + Water Depth model for nest-site selection of American Coot nests monitored during May-August 2013-2019 at Emiquon Preserve, Fulton County, Illinois, USA.

\begin{tabular}{lcc} 
Predictors & Odds Ratios & CI \\
\hline (Intercept) & 0.37 & $0.12-1.17$ \\
Dense Emergent & 1.32 & $0.52-3.30$ \\
Water Depth & 100.53 & $3.22-3134.53$ \\
Water Depth & \\
& \multicolumn{1}{c}{0.05} & $0.00-1.01$ \\
Random Effects $^{2}$ & \\
$\sigma^{2}$ & 3.29 & \\
$\tau_{00}$ yr & 1.09 & \\
ICC & 0.25 & \\
$\mathrm{~N}_{\text {yr }}$ & 7 & \\
\hline Observations & 71 & \\
$\mathrm{Marginal} \mathrm{R}^{2}$ & 0.456 &
\end{tabular}


Appendix 5. Model results from the habitat + Open Water model for nest site selection of

Common Gallinule nests monitored during May-August 2013-2019 at Emiquon Preserve, Fulton County, Illinois, USA.

\begin{tabular}{lcc} 
Predictors & Odds Ratios & CI \\
\hline (Intercept) & 0.23 & $0.13-0.42$ \\
Open Water & 0.99 & $0.60-1.65$ \\
habitat [Persistent] & 3.33 & $1.05-10.53$ \\
Random Effects & & \\
$\sigma^{2}$ & 3.29 & \\
$\tau_{00}$ yr & 0.00 & \\
$\mathrm{~N}_{\text {yr }}$ & 5 & \\
\hline Observations & 90 & \\
Marginal R & 0.061
\end{tabular}


Appendix 6. Model results from the Dense Emerge + Water Depth model for nest site selection of Least Bittern nests monitored during May-August 2013-2019 at Emiquon Preserve, Fulton County, Illinois, USA.

\begin{tabular}{lcc} 
Predictors & Odds Ratios & CI \\
\hline (Intercept) & 0.14 & $0.09-0.23$ \\
Dense Emergent & 2.98 & $1.74-5.12$ \\
Water Depth & 7.79 & $1.64-36.95$ \\
Water Depth $^{2}$ & 0.16 & $0.03-0.93$ \\
Random Effects & & \\
$\sigma^{2}$ & 3.29 & \\
$\tau_{00}$ yr & 0.00 & \\
$\mathrm{~N}_{\text {yr }}$ & 7 & \\
\hline Observations & 198 & \\
Marginal R $^{2}$ & 0.278
\end{tabular}

